\title{
HRAD V HRÁDNÍKÁCH U ZÁŘECKÉ LHOTY NA CHOCEŇSKU
}

\section{DAVID VÍCH}

\begin{abstract}
Abstrakt: Na ostrožně v areálu pravěkého hradiště v poloze Hrádníky (k. ú. Zářecká Lhota, Pardubický kraj) vznikl na konci 13. či počátkem 14. století hrad postavený za použití dřeva, kamene a hlíny. Hrad existoval relativně krátkou dobu a zanikl náhlým požárem. Vedle movitých nálezů pro hradní prostředí obvyklých (výstroj koně a jezdce, stavebni kování, militaria, zemědělské náčiní, predměty osobni potřeby) se zde setkáváme i s artefakty méně obvyklými, jako zlomek ramene skládacích vážek či slitkové stř́bro. $V$ hradním prostředi zcela unikátním nálezem je torzo ostatkového křiže.
\end{abstract}

Klíčová slova: hrad-vrcholný středověk - železné artefakty-střibro-ostatkový kríž.

\section{Castle in Hrádníky Near Zářecká Lhota in the Chocen̆ District}

Abstract: A castle of wood, stone and earth was built in the late 13th century or in the early 14th century on a promontory in the area of a prehistoric hillfort at Hrádniky (Zárecká Lhota cadastral zone, Pardubice Region). The castle only existed briefly and was destroyed by a sudden fire. Apart from finds typical of the castle milieu (gear for horses and riders, building fittings, militaria, agricultural tools, personal items), the research yielded less usual artefacts such as a fragment of the shoulder of a set of foldable scales and cast silver. The find of a part of a reliquary cross is unique in the castle environment.

Key words: castle - high Middle Ages - iron artefacts - silver - reliquary cross.

\section{1 Úvod}

Hradu nad osadou Hrádníky poblíž Chocně (k. ú. Zářecká Lhota, okr. Ústí nad Orlicí, Pardubický kraj), ač dlouhodobě známého, se archeologická literatura dotkla zatím pouze minimálně. Preventivní detektorový průzkum prováděný v uplynulých letech Regionálním muzeem ve Vysokém Mýtě spojený s geodetickým zaměřením celé lokality nás staví před potřebu celkového zhodnocení lokality s důrazem na výpověd’ získaných movitých nálezů. Prezentované movité archeologické nálezy jsou, pokud není uvedeno jinak, majetkem Pardubického kraje a jsou uloženy v Regionálním muzeu ve Vysokém Mýtě v podsbírce archeologie s inv. č. 5730-5738, 6252-6253, 7555-7605.

\section{Choceň a Choceňsko v pramenech}

Pomineme-li období pravěku, bylo Choceňsko ve svých nejúrodnějších částech sporadicky osídleno již ve střední době hradištní (Profantová-Vích 2012). Do mladší doby hradištní klade V. Vokolek zlomky raně středověké keramiky zjištěné při výzkumu hradiště nad Darebnicemi, na rozhraní k. ú. Běstovice a Choceň $(1993,51)$. Stejnému období nepochybně náleží i celá lahvovitá nádobka nalezená v písníku na poli za stavením p. Lásky v roce 1928 v Běstovicích (Vích 2009, 4). Nevelká kolekce nálezů z mladší doby hradištní z Hrádník pocházející s největší pravděpodobností z prostoru hradiště v k. ú. Zářecká Lhota (nikoliv pouze vrcholně středověkého opevnění) vedla k datování hradiště do mladší doby hradištní (Vencl 1971, 27), pravěký původ lokality prokázal až výzkum V. Vokolka (1990). Středověké Choceňsko pak bylo plně osídleno až kolonizací ve 13. století (Musil 2002, 126-128).

Sama Choceň do písemných pramenů poprvé vstupuje v roce 1227, kdy ji Kojata Hrabišic odkazuje služebníkům Milotovi a Sezemovi (CDB II, 301 č. 303). Další zmínka se váže k roku 1292, kdy Choceň vlastní Václav II., který ji spolu s dalšími vesnicemi v okolí a jiným pozemkovým majetkem postupuje nově založenému klášteru na Zbraslavi (RBM IV, 745 č. 1888). O tom, že majetkové vztahy v Chocni mezi dárcem, králem Václavem II., a obdarovaným, zbraslavským klášterem, byly komplikovanější, svědčí list Burcharda, arcibiskupa magdeburského, Heřmanovi, kaplanovi krále Václava II., s žádostí o př́ímluvu u krále, protože prý král chce stavět v Chocni hrad, a tím ohrožuje klášterní práva (Loserth 1896, 77-78, č. 87). O motivech panovníka se 
můžeme jenom dohadovat. Na existenci hradu ukazuje list Mikuláše z Potštejna lazebníkovi v městečku Kostelci, v němž zmiňuje Hynka z Chocně (,Hinczici miles de Choczna“) považovaného za purkrabího na hradě tehdejšího majitele Chocně Mikuláše z Potštejna (Sedláček 1883, 248). O hradě v Chocni nedlouho poté píše i Karel IV., který ve svém životopise Vita Caroli k roku 1338 uvádí: „Téhož léta jsem přijel k Vysokému Mýtu a zbořil jsem hrad Choceň a četné hrady pána z Potštejna, nebot' jsem toho času vedl válku s tímto pánem (...)“ (podle Bláhová a kol. 1987, 38). Žádnou z uvedených písemných zpráv však bohužel nemůžeme s jistotou vztáhnout k lokalitě dochované do dnešních dnů v okolí Chocně, s jistotou nemůžeme dokonce tvrdit ani to, že se písemné zprávy vážou k téže stavbě.

V okolí Chocně se nacházejí, pokud pomineme pravěké hradiště nad osadou Darebnice s železnou pravidelností v literatuře zaměňované za nedaleký vrcholně středověký Hlavačov, celkem čtyři vrcholně středověké opevněné lokality (obr. 1). ${ }^{1}$ Vedle opevnění v poloze Hrádníky v k. ú. Zářecká Lhota, kterému je věnován tento př́íspěvek, jde o Vranov (nazývaný též Koutníkov) ležící nedaleko choceňského hřbitova nad srázy na pravém břehu Tiché Orlice (k lokalitě Sedláček 1883, 246; Musil 1995, 35). Hrad však velmi silně narušily či zničily terénní úpravy, přičemž archeologické nálezy uložené v choceňském muzeu dnes již není možné identifikovat. Na levém břehu Tiché Orlice na výrazné terase leží hrad nazývaný Hlavačov. V historii archeologicky zkoumané lokality jsou zřetelně odlišitelné dvě fáze, starší ze 13. století a mladší ze 14. století (naposled Cejpová 2002; 2006). Posledním hradem v okolí Chocně je hrad Zítkov datovaný do pokročilého 14. až počátku 15. století (Musil 1995, 35-36), což se zcela shoduje s nově získanými archeologickými prameny.

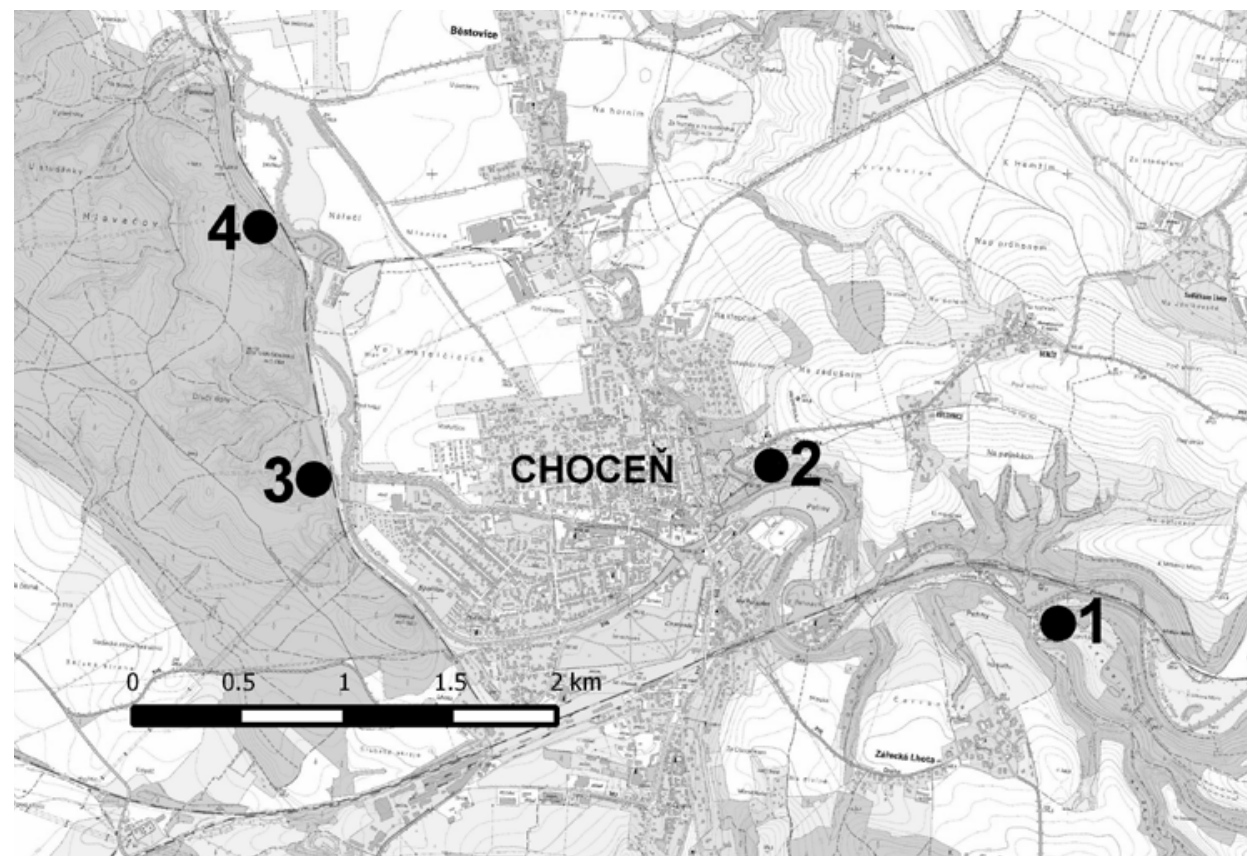

Obr. 1. Okolí Chocně s vyznačenými polohami vrcholně středověkých fortifikací. 1 - Zářecká Lhota, Hrádníky; 2 - Choceň, Koutníkov - Vranov; 3 - Choceň, Zítkov; 4 - Choceň, Hlavačov.

Abb. 1. Umgebung von Choceň mit eingezeichneten Lagen der hochmittelalterlichen Befestigungen. 1 - Zár̆ecká Lhota, Hrádníky; 2 - Choceň, Koutníkov - Vranov; 3 - Choceň, Zítkov; 4 - Choceň, Hlavačov.

1 Opevnění v poloze Hrádníky v k. ú. Zářecká Lhota nebývá tradičně řazeno k tzv. choceňským hradům a tvrzím (viz Sedláček 1883, 246-254) a bývá spojováno s nedalekým brandýským panstvím (Sedláček 1883, 146). Tento stav však reflektuje až situaci v pozdním středověku a novověku. Na konci 13. a počátku 14. století, kam spadá doba existence hradu, mohla být situace jiná, a to už jenom s ohledem na vzdálenost opevnění od historického centra Chocně. 
Nejednoznačná výpověd' písemných pramenů spolu s existencí více vrcholně stř̌edověkých opevněných lokalit v okolí Chocně pak přirozeně vedou ke vzniku řady hypotéz pokoušejících se $\mathrm{s}$ větši či menší pravděpodobností ztotožnit výpověd' hmotných a písemných pramenů. Starší fázi Hlavačova spojuje F. Musil s hradem, o jehož plánovaném založení se dozvídáme z listu magdeburského biskupa ze samého závěru 13. století (1995, 36-37). I když nálezy z hradu v rámci 13. století zatím přesněji datovat nedokážeme, jsou zcela jistě starší než z přelomu 13. a 14. století, na což správně poukázala již M. Cejpová $(2002,131)$. Mladší fázi téhož hradu jednoznačně ztotožňuje M. Cejpová s hradem dobytým Karlem IV. v roce 1338, bohužel bez zevrubnějšího vyhodnocení archeologických pramenů $(2006,131)$, této problematice proto bude nutné se věnovat samostatně. Vranov dle A. Sedláčka $(1883,248)$ ztotožňoval s hradem dobývaným Karlem IV. již Tomáš Pešina z Čechorodu, nově pak tuto myšlenku zastává F. Musil $(1995,37)$.

Na základě výše uvedeného nezbývá než konstatovat, že neznáme dobové označení hradu v poloze Hrádníky, a nemůžeme k němu s jistotou vztáhnout žádné písemné prameny.

\section{Popis lokality}

Místo studované fortifikace se nachází necelé $2 \mathrm{~km}$ východně od historického centra Chocně v k. ú. Zářecká Lhota při jeho severním okraji. Vrcholně středověké opevnění je situováno na samém hrotu ostrožny ze severu a východu obtékané Tichou Orlicí, která zde vytváří hluboce zaříznuté údolí s příkrými svahy, a nad údolím neméně výrazně modelovaného Ostroveckého potoka obtékajícího lokalitu z jihu (obr. 2). Převýšení nad Tichou Orlicí činí ca $25 \mathrm{~m}$. Stavitelé hradu využili strategického místa tvořeného opukovými skalními věžemi v nadmořské výšce okolo $320 \mathrm{~m}$. Celou plochu ostrožny včetně areálu vrcholně středověké fortifikace využili již dříve lidé v pozdní době bronzové jako hradiště.

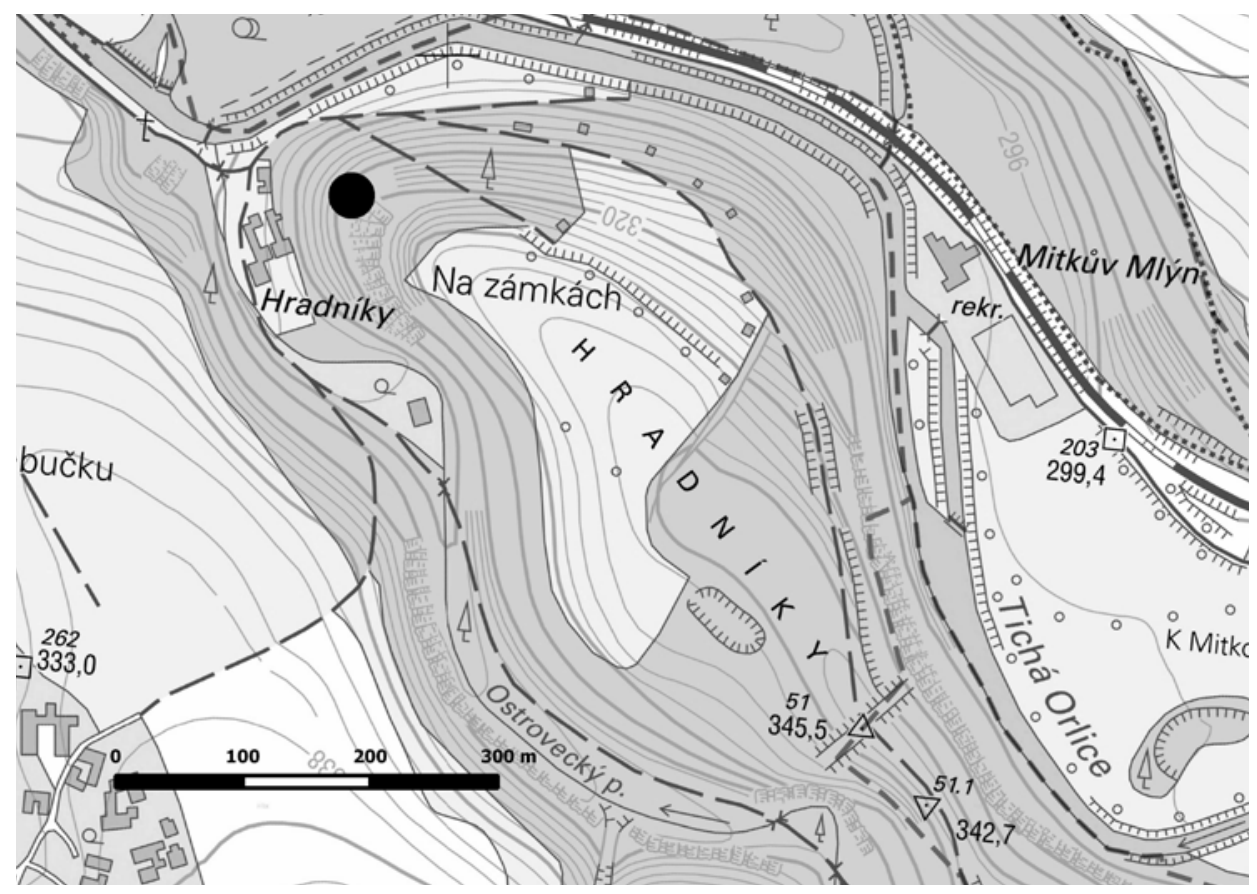

Obr. 2. Zářecká Lhota - Hrádníky. Širší okolí lokality. Podklad ZM 1 : 10000.

Abb. 2. Zářecká Lhota - Hrádníky. Weitere Umgebung der Fundstelle. Vorlage Grundkarte 1 : 10000. 


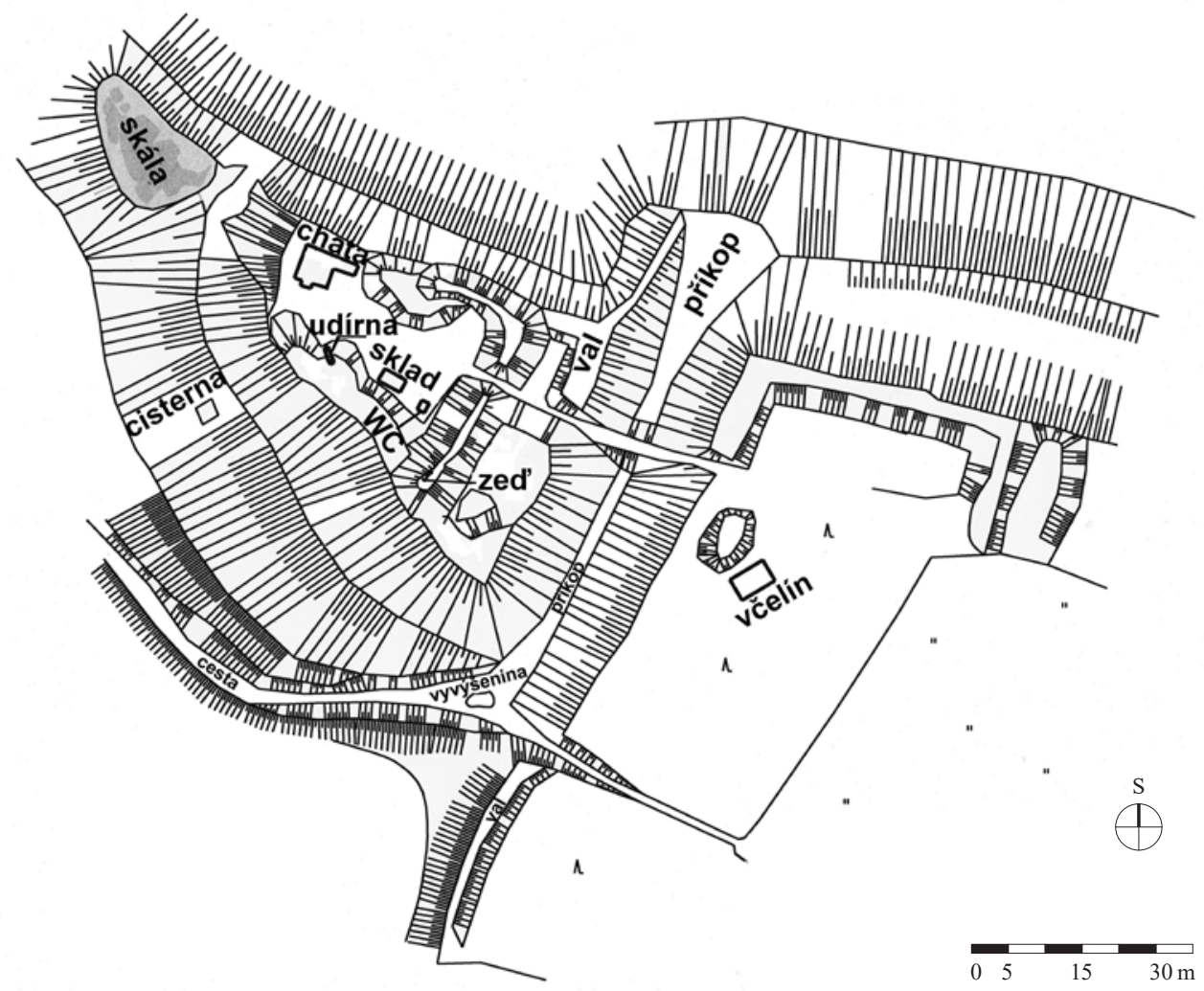

Obr. 3. Zářecká Lhota - Hrádníky. Geodetický plán lokality. Vyhotovila Zeměměřičská kancelář v Kostelci nad Orlicí.

Abb. 3. Zářecká Lhota - Hrádníky. Geodätische Planskizze der Fundstelle. Erstellt vom Büro für Landesvermessung in Kostelec nad Orlicí.

Plocha areálu hradu zarostlá listnatým až smíšeným lesem je od předpolí oddělena $5 \mathrm{~m}$ hlubokým a 20 m širokým uměle vylámaným příkopem (obr. 3). V prostoru před příkopem vně plochy hradu se v areálu pravěkého hradiště nachází „,neklidný“ terén v podobě terénní deprese situované u dřevěné stavby s kamennou podezdívkou (bývalý včelín) a zvýšené hrany při okraji hradiště. Bez archeologického výzkumu nelze jednotlivé stopy s jistotou datovat. Zatímco deprese působí vysloveně „mladým“ dojmem, u valovitého útvaru nemůžeme říci, zda vznik1 snížením terénu vnitřní plochy, či zda jde o zbytek navršeného pravěkého valu.

Uvnitř plochy hradu se nad př́ikopem nachází obdélníkovitá plošina situovaná delšími stranami napříč ostrožnou (obr. 4), přičemž nároží plošiny nad příkopem jsou vyvýšena. Dle mikrovrypů prováděných zde při detektorovém průzkumu v sobě tyto vyvýšeniny uchovávají intaktní archeologické situace (mazanicová destrukce) a jde patrně o zbytky lehčí zástavby.

Plošinu nad př́ikopem odděluje od vnitřního areálu hradu výrazné valové těleso skrývající v sobě kamennou strukturu krytou destrukčním kuželem, z níž je v jižní části tohoto valového tělesa obnaženo nároží, odkryté v roce 1964 (obr. 5). Vnitřní prostor fortifikace (obr. 6) tvoří plocha postupně se zdvihající jižním i severním směrem, přičemž žádné jiné zbytky původní vnitřní zástavby nejsou patrné. Terénní vlnu při jižní hraně tvoří dle výsledků mikrovrypů prakticky v celé její délce destrukce z tvrdě vypálené mazanice obsahující otisky konstrukce. Severní terénní vlnu kryje na povrchu recentní vrstva odpadu a popela související s provozem víkendové chaty, o charakteru případných situací pod těmito recentními navážkami nevíme nic.

Zatímco oproti ploše hradu o něco snížený samotný hrot ostrožny tvoří izolované opukové suky s minimem půdního pokryvu beze stop umělé úpravy terénu, důležitý prostor, totiž vrchol 


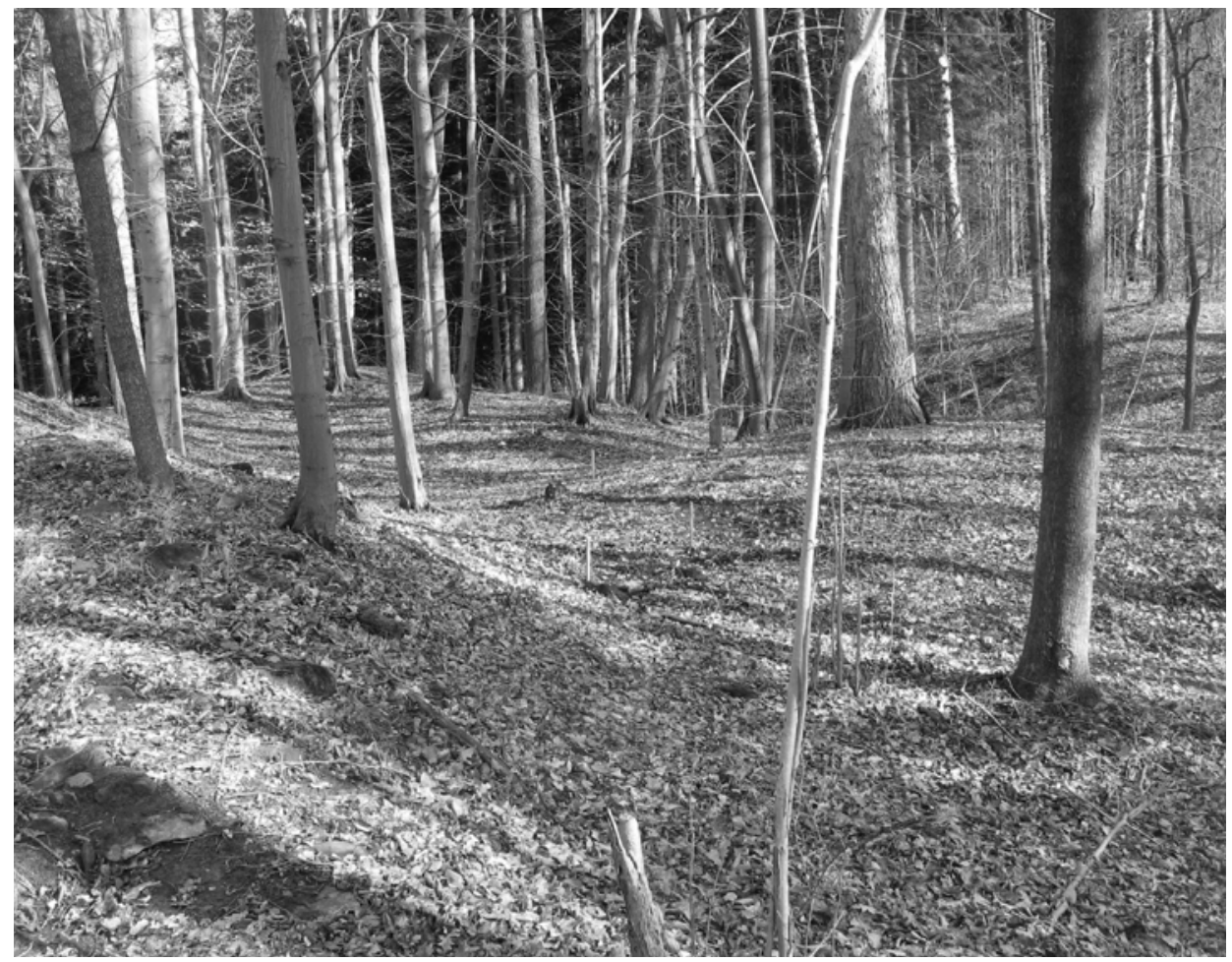

Obr. 4. Zářecká Lhota - Hrádníky. Plošina nad příkopem. Prostor s nálezy slitků stř́íbra, jednoho z parvů Václava II. a zlomků skládacích vážek. Pohled k severovýchodu.

Abb. 4. Zářecká Lhota - Hrádníky. Plateau oberhalb des Grabens. Fundraum der Silbergussstücke, eines Parvus von Wenzel II. und eines Klappwaagenfragmentes. Blick nach Nordosten.

přibližně podkovovitě uspořádaného jádra byl v roce 1938 zničen stavbou chaty tvořené bytelnou podezdívkou s dřevěnou konstrukcí (Musil 1995, 32), jíž bezprostředně předcházelo snížení a srovnání terénu. Archeologické nálezy objevené při této př́iležitosti skončily v choceňském muzeu, ovšem pravděpodobně zdaleka ne všechny. Dle ústního svědectví majitelů z počátku 90. let 20. století byly snad některé keramické nálezy „uloženy“ do zděné podezdívky. Terénní úpravy předcházející stavbě chaty tak vzhledem k míře zahloubení s největší pravděpodobností zcela zničily nejchráněnější místo fortifikace, kde můžeme důvodně předpokládat existenci obytné budovy sloužící majitelům hradu, a patrně tak otázku zástavby tohoto prostoru definitivně vyřsšily.

Také další doplňkové stavby doprovázející užívání chaty narušily intaktní situace v areálu opevnění. Jde především o udírnu sestávající z železné hranolové konstrukce určenou pro vlastní konzervaci masa a z topeniště propojeného s prostorem k uzení tažným kanálem zahloubeným pod zem a opětovně zasypaným. Terénní úpravy v tomto prostoru, prováděné patrně již v souvislosti se stavbou chaty a pozdějším zřízením udírny, významně zasáhly intaktní situace uchované v jižní terénní vlně v blízkosti hrotu ostrožny. O citelné devastaci tohoto prostoru svědčí vedle četného recentního odpadu také nález parvu Václava II. v druhotné poloze poblíž ohniště využívaného majiteli chaty. Další zásahy představuje alespoň podle aktuálního stavu (konec r. 2014 - počátek r. 2015) stavba jednoduchého přístřešku sloužícího jako skladiště (palivové dříví aj., v tomto př́ípadě jsou zásahy pod úroveň terénu minimální) a především výkop suchého WC, který nepochybně archeologické situace narušil. Dokumentace stěn výkopu aktivně využívané toalety by jistě mohla přinést konkrétnější informace o charakteru narušených situací, $\mathrm{k}$ tomu však autor těchto řádků nenašel odvahu. 


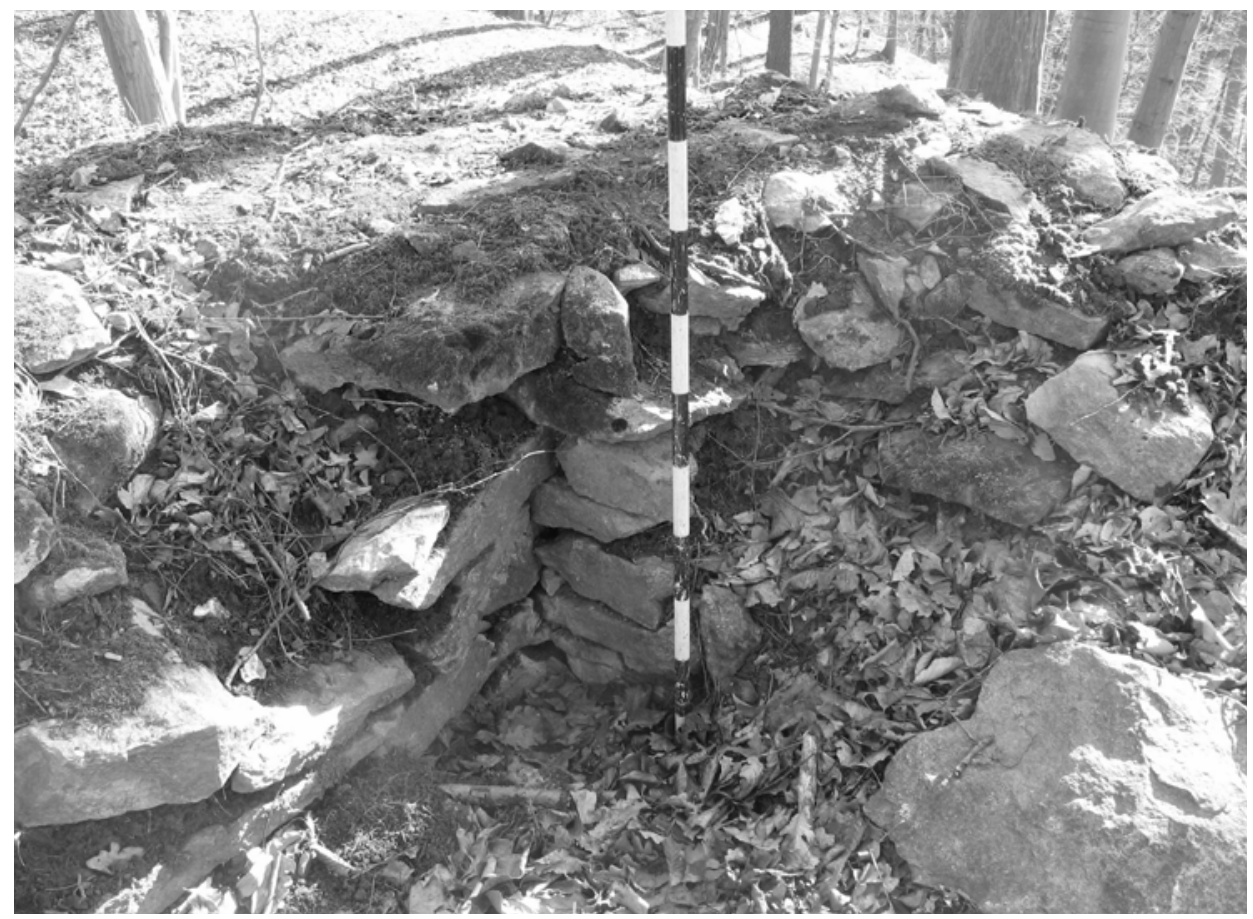

Obr. 5. Zářecká Lhota - Hrádníky. Odkryté nároží z kamene.

Abb. 5. Zářecká Lhota - Hrádníky. Freigelegte Mauerecke.

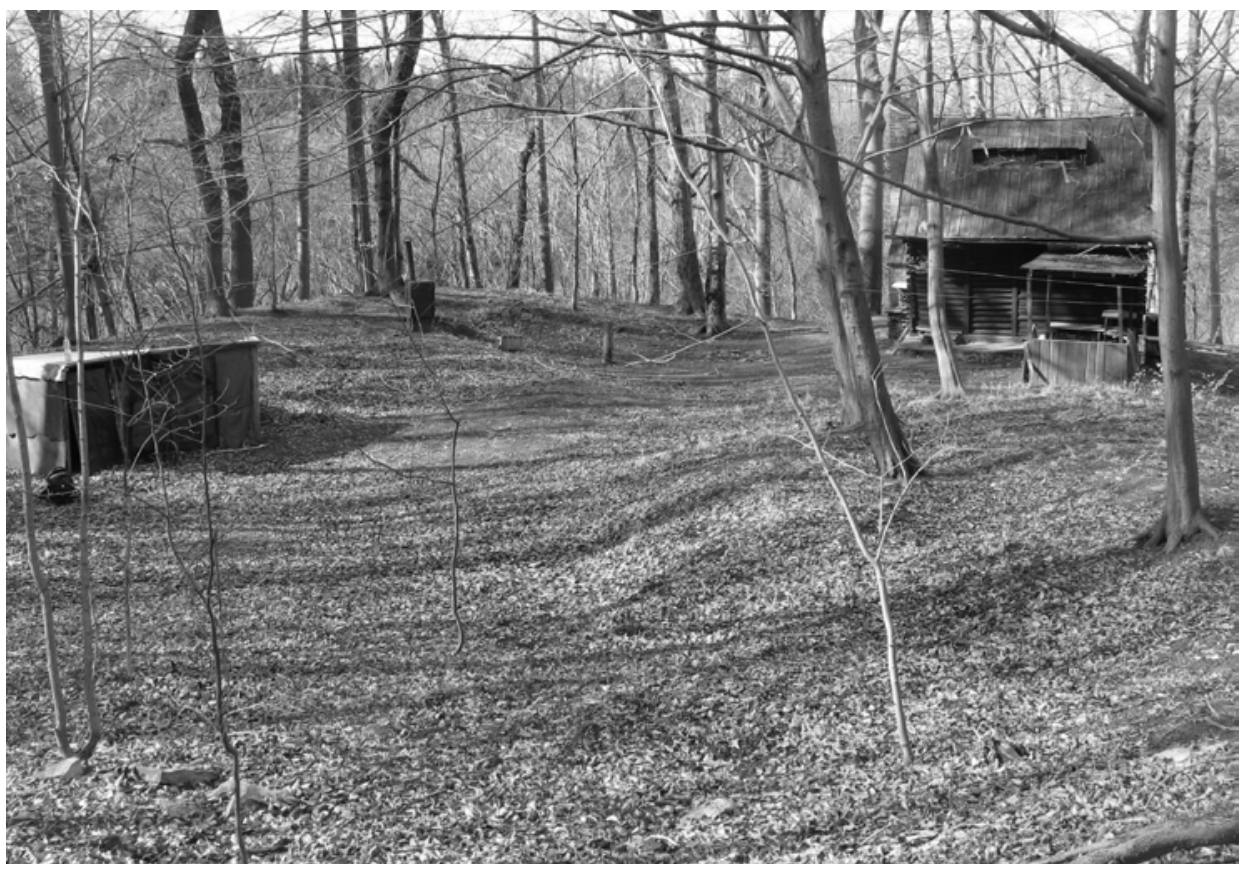

Obr. 6. Zářecká Lhota - Hrádníky. Jádro lokality. Pohled k jihozápadu.

Abb. 6. Zářecká Lhota - Hrádníky. Kernburg. Blick nach Südwesten. 


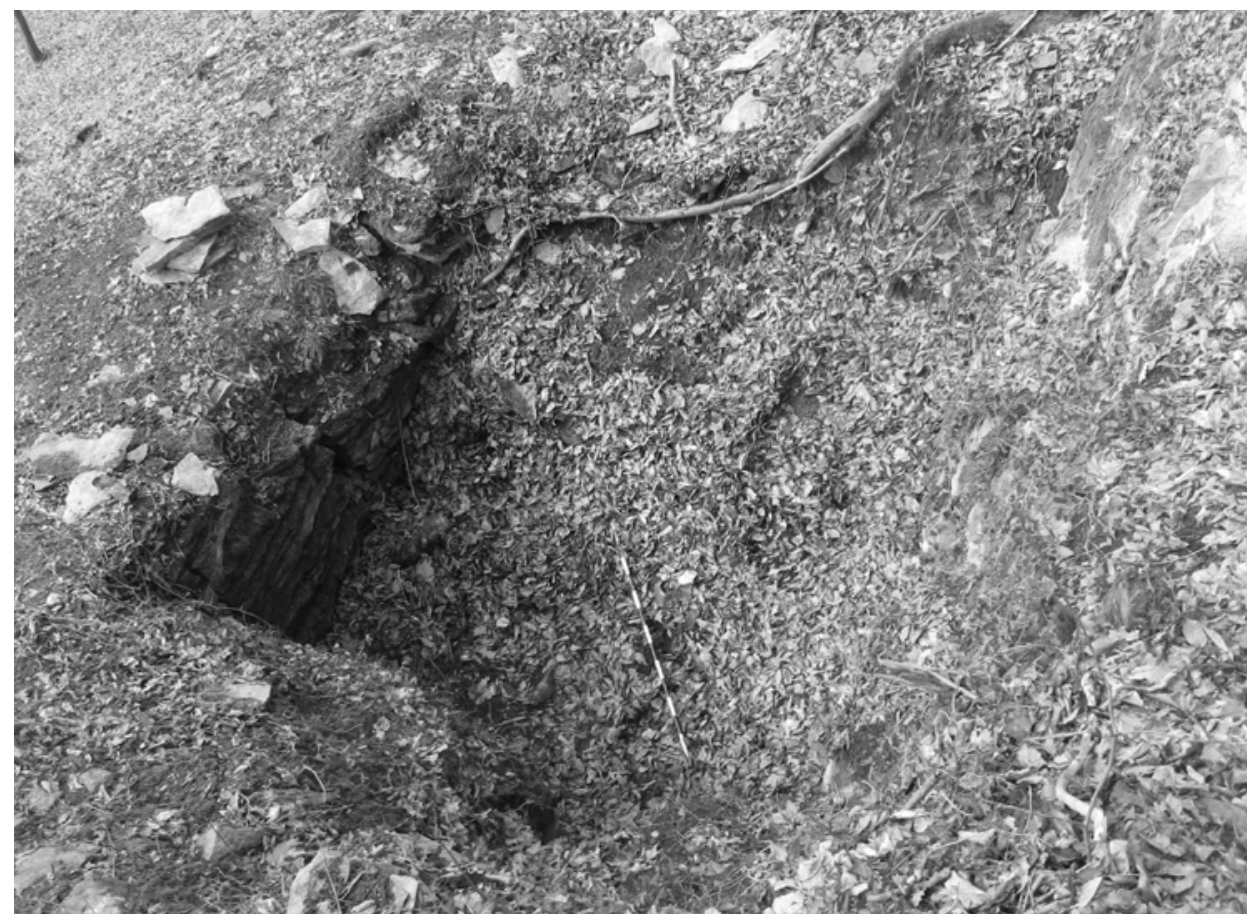

Obr. 7. Zářecká Lhota - Hrádníky. Jižní svah fortifikace - pohled do studny či cisterny.

Abb. 7. Zářecká Lhota - Hrádníky. Südhang der Befestigung - Blick auf einen Brunnen bzw. eine Zisterne.

Na jižním svahu ostrožny se nachází obdélný objekt vytesaný do opukové skály pod skalní stěnou, interpretovatelný nejspíše jako studna či spíše cisterna (obr. 7). Datování objektu zůstává otevřené, souvislost s fortifikací se (i podle stavu zvětrání skály) jeví jako pravděpodobná.

Pro úplnost dodejme, že dle informací paní Voženílkové z roku 1969 a dalších zdrojů (informace je tradována ústně) se zde měly rovněž nacházet podzemní chodby, později zasypané lesníky. Přítomnost pseudokrasových člověkem využívaných puklin je zde skutečně dobře možná, zpráva o bloudění případného návštěvníka a o existenci velké místnosti však nepůsobí věrohodně.

Samostatnou pozornost si zaslouží komunikační schéma. Dnes je hradní jádro přístupné především pěšinou vinoucí se od Tiché Orlice po severním svahu pravěkého hradiště až do hradního příkopu při jeho severním vyústění. Mladšího data je rovněž přístup z louky před areálem fortifikace po pěšině, která běží např́ič příkopem po druhotně navezeném náspu a před vstupem do hradního jádra proráží valové těleso uchovávající relikt zdi. Soudobá naopak může být po jižním svahu obloukovitě stoupající výrazná úvozová cesta (obr. 3, 8), která se posléze rozdvojuje. Jedno její rameno běží přímým směrem mimo hrad do dnes zatravněného areálu pravěkého hradiště (val jižně od hradu je s největší pravděpodobností již pravěký), druhá větev se stáčí a ústí do hradního příkopu z jihu. Jak a kudy se vcházelo přímo do hradního areálu, není však z dnešního stavu terénu zřejmé.

Na základě dostupných informací si lokalitu můžeme představit jako stavbu na podkovovitém půdorysu s obvodovou zástavbou oddělenou od předpolí hlubokým příkopem. Hlavním obranným prvkem byla pravděpodobně kamenná hradba, dnes relikt zdi krytý destrukčním kuželem probíhající napříč ostrožnou, která dle pravoúhlého nároží v jižní části mohla chránit složitější zástavbu zevnitř přiléhající $\mathrm{k}$ hradbě. Zástavba pak pokračovala dle existence výrazné terénní vlny podél jižní hrany areálu, ovšem množství tvrdě vypálené mazanice ukazuje na výrazný (výhradní?) podíl dřevohlinité architektury. Podobně tomu mohlo být i podél severního obvodu areálu, o charakteru archeologických situací zde však pro subrecentní navážky v podobě 


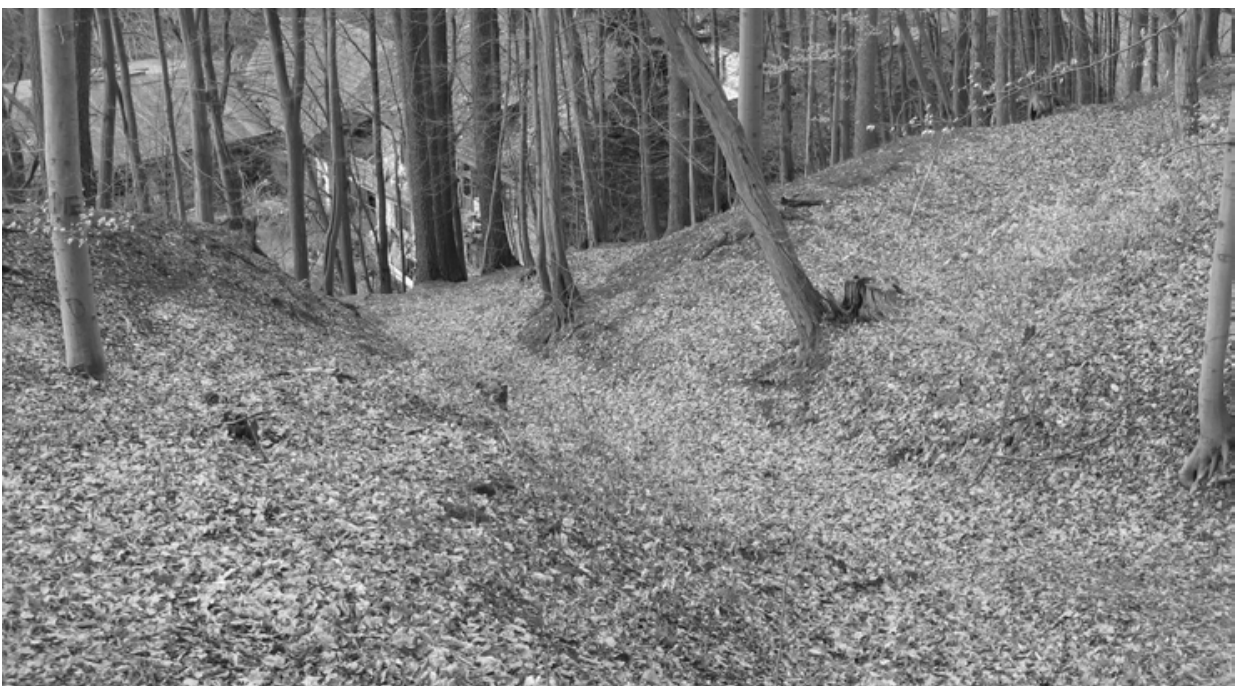

Obr. 8. Zářecká Lhota - Hrádníky. Úvozová cesta pod jižním svahem hradu.

Abb. 8. Zářecká Lhota - Hrádníky. Hohlweg unterhalb des Burgsüdhangs.

komunálního odpadu a popela nevíme vůbec nic. Bez jakýchkoliv informací rovněž zůstáváme i v prŕípadě samého hrotu ostrožny (hlavní obytná budova?) zničeného stavbou chaty. Zástavba s využitím dřeva a hlíny se nacházela i v úzkém obdélníkovitém prostoru mezi hradním př́íkopem a kamennou zdí. O možném předhradí pak nevíme vůbec nic. I když zde terén vykazuje zásahy nepochybně antropogenního původu, nedokážeme odlišit vrcholně středověké úpravy od úprav recentních a pravěkých. Movité nálezy zde s výjimkou torza ostruhy č. 18 a bronzového slitku (spojovaného s pravěkým osídlením) zjištěny nebyly.

\section{Historie poznávání lokality}

V literatuře se informace o opevnění objevují již v 19. století (souhrnně Musil 1995, 32) a zájem o lokalitu má dlouhodobější trvání, ale ne všechny aktivity jsme schopni postihnout, popř. rozlišit, zda se týkaly celého areálu pravěkého hradiště, nebo pouze části s vrcholně středověkým opevněním.

Při úpravě terénu v rámci stavby chaty nalezl její majitel v prostoru severní terénní vlny ve vnitřním prostoru fortifikace (obr. 9:I) dvě ostruhy (,jedna bez ozub. kolečka“). K dalšímu terénnímu zásahu, který vedl k objevu archeologických předmětů, došlo někde u jižního zvýšeného nároží v prostoru před příčným valem skrývajícím zed’ (obr. 9:II) dne 10. 6. 1942. Tehdy nalezli dělníci při dobývání pařezů soubor kovových artefaktů a keramiky, sekeru, nůž, hřeby, závěsný hák, neurčený předmět (,součástka bud’ zámku nebo kuše“), keramiku (zdobenou „vodorovným rýhováním, vlnovkou i šikmočarým meandrem“) a mazanici s otisky dřevěné konstrukce. O obou akcích jsme informováni díky anonymnímu zaměstnanci choceňského muzea, který vyhotovil detailní kolorovaný plán s komentářem (výřez na obr. 9). V něm chybí zmínka o nálezu ostruhy učiněném rovněž při této př́íležitosti, ostruha se však na rozdíl od ostatních předmětů dochovala do dnešních dnů ve sbírkách choceňského muzea i s nálezovými okolnostmi (Vích 2009, 33, obr. 70:3). ${ }^{2}$

Dne 7. 6. 1964 navštívili lokalitu členové archeologické sekce při tehdejším Orlickém vlastivědném muzeu v Chocni M. Svatoš a J. Svoboda spolu se zaměstnancem muzea L. Šalým. Zaměřili se na okolí chaty, kde podle svědectví jejího majitele A. Ella při deštích voda stékající ze

2 Plán je uložen v archivu Orlického muzea v Chocni ve složce „Hrádníky“. 


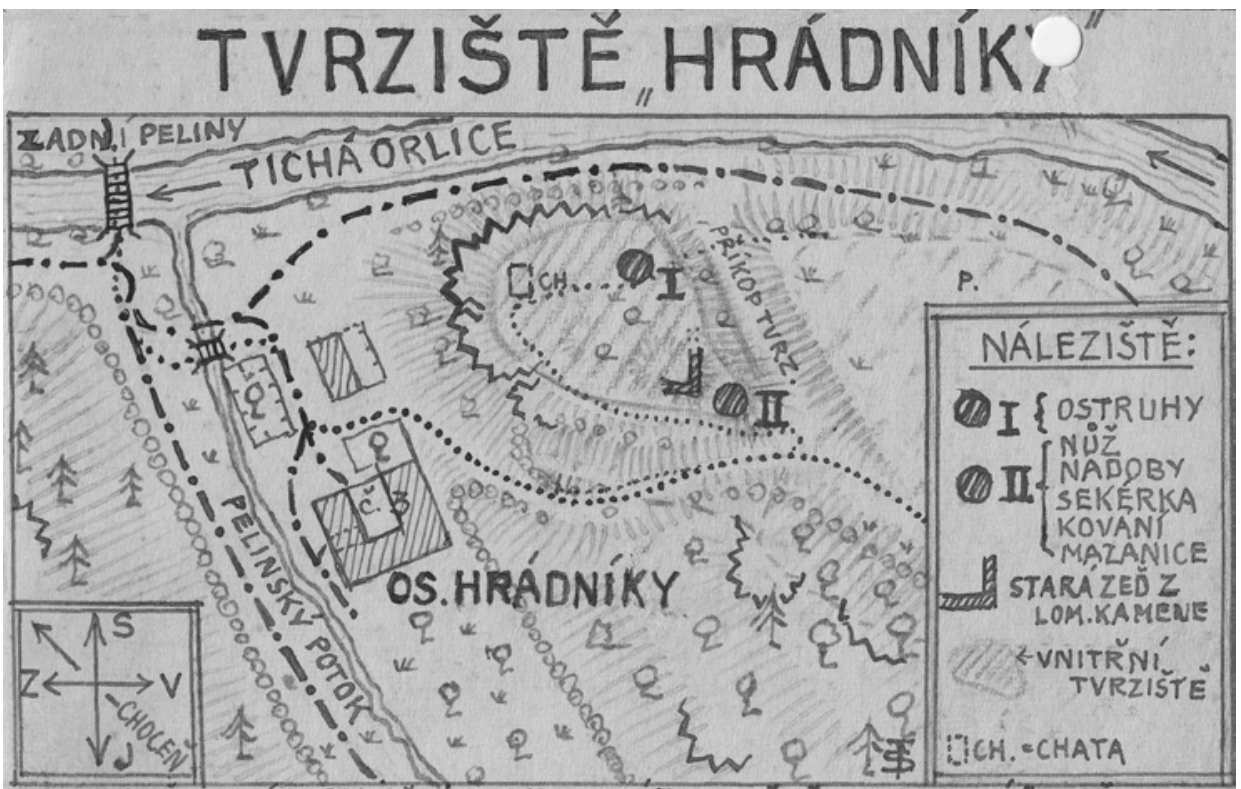

Obr. 9. Zářecká Lhota - Hrádníky. Plán hradu s vyznačenými staršími nálezy. Zdroj archiv Orlického muzea v Chocni. Abb. 9. Zářecká Lhota - Hrádníky. Planskizze der Burg mit eingezeichneten älteren Funden. Quelle Archiv des Museums des Adlergebirges in Choceň.

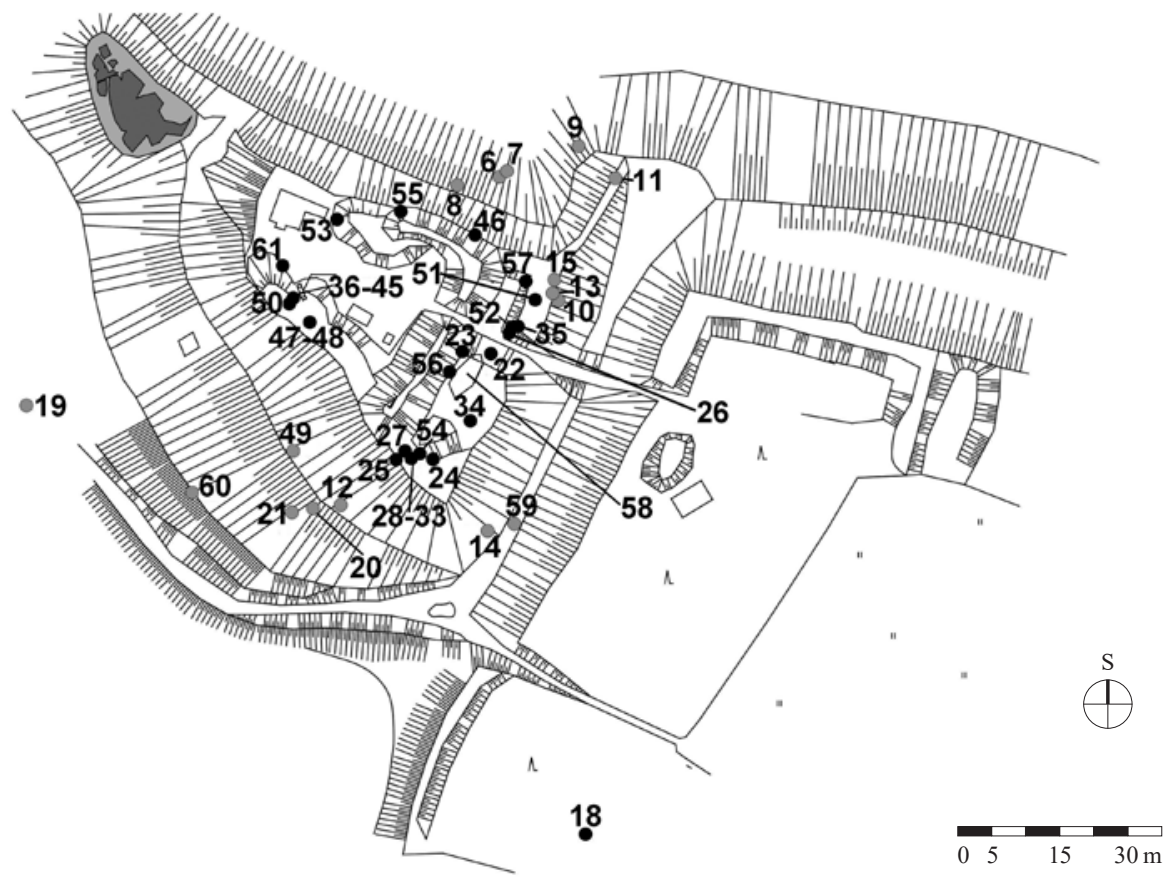

Obr. 10. Zářecká Lhota - Hrádníky. Geodetický plán lokality s vynesenou polohou nálezů v programu Quantum GIS. Černě - geodeticky zaměřené nálezy, šedě - nálezy zaměřené ruční stanicí GPS. Číslování na obrázku odpovídá číslování v katalogové části práce.

Abb. 10. Zářecká Lhota - Hrádníky. Geodätische Planskizze der Fundstelle mit gekennzeichneter Lage der Funde im Program Quantum GIS. Schwarz - geodätisch vermessene Funde, grau - mit einer GPS-Handstation vermessene Funde. Die Nummerierung auf der Abbildung entspricht der Nummerierung im Katalogteil der Arbeit. 
střechy vymílala střepy, což svým pozorováním v okolí severozápadního nároží chaty potvrdili (i když nacházeli především mazanici). Dále se věnovali valovému tělesu kryjícímu zdivo, z něhož v jižní části obnažili nároží složené na sucho z lomového kamene, ${ }^{3}$ které je patrné dodnes.

Do odborné archeologické literatury vstoupil hrad až výše citovanou prací zásluhou S. Vencla (1971, 22-29), který publikoval i plán lokality. S. Vencl pak hrad datoval dle nálezů $\mathrm{z}$ choceňského muzea $\mathrm{k}$ přelomu 14. a 15. století. Lokalitě, ovšem pouze pravěkému hradišti, v jehož areálu se hrad nachází, později věnoval pozornost V. Vokolek, který zde v roce 1989 provedl menší zjišt’ovací výzkum. Ten prokázal pravěké stáří hradiště s datováním do závěru doby bronzové (Vokolek 1990), vrcholně středověkého opevnění se však výzkum nedotk1. Starší movité nálezy ze středověké fortifikace v Hrádníkách byly nedávno zveřejněny v rámci zpracování nálezů v Orlickém muzeu v Chocni do podoby katalogu (Vích 2009, 33-35, obr. 69:7-11; 70-73; 74:1-14).

Nově pramennou základnu dále rozšíríila také akce realizovaná v rámci projektové výuky Mgr. Martinou Krskovou ze ZŠ Svatopluka Čecha v Chocni. Při ní se žáci v průběhu roku 2011 seznamovali s hradem, jeho historií a okolní př́irodou. Součástí projektu (prováděného ve spolupráci s archeologem Regionálního muzea ve Vysokém Mýtě) byl i sběr erozí vynesené keramiky na svazích fortifikace s následným předáním nálezů do vysokomýtského muzea.

Povrchovou prospekci, tentokrát i s využitím detektoru kovů, zde prováděl ve dvou kampaních také autor spolu se spolupracovníky Regionálního muzea ve Vysokém Mýtě. První (individuální) akce zaměřená na svahy fortifikace proběhla v roce 2009, druhá kampaň, tentokrát i s účastí spolupracovníků, pak až koncem roku 2014 a počátkem roku 2015. Při detektorové prospekci byly používány př́stroje Fisher 75, XP Deus, Teknetics T2, XP Goldmaxx Power II, AKA Signum, Nokta Fors Gold s časovou dotací 42 h po přepočtu na jeden prŕstroj. Průzkum probíhal v režimu ALL METAL, přičemž jednoznačně určitelný recentní odpad byl odnášen a kované železné hřeby (většinou nejspíše vrcholně středověkého stáří) byly vráceny zpět na místo nálezu. Nálezy jsme zaměřovali dvojím způsobem. Na svazích ve splachových vrstvách byly zaměřovány ruční stanicí GPS (měřeno v UTM, WGS 84 s využitím př́istrojů Garmin Geko 201 a Garmin Etrex 20), v areálu fortifikace, kde se dalo počítat s přítomností intaktních archeologických situací (což se následně plně potvrdilo), pak navíc i totální stanicí (obr. 10). Při této př́ležitosti byl rovněž vyhotoven geodetický plán lokality (zaměření provedla Zeměměřičská kancelář Kostelec nad Orlicí, Ing. Jiř́i Němec). Ve dvou prrípadech pak zjištěná situace vyžadovala preparaci s provedením fotografické a kresebné dokumentace.

První kumulaci kovových předmětů jsme dokumentovali na plošině mezi přičným valem a příkopem v jižním zvýšeném nároží. Dvě ostruhy s vidlicí a s dochovaným upínacím mechanismem (u jedné ostruhy ovšem chybělo kolečko) se nacházely $5 \mathrm{~cm} v$ písčitojílovité šedé vrstvě promísené okrovou s keramikou a tvrdě vypálenou mazanicí (kontext 101) a $22 \mathrm{~cm}$ pod úrovní stávajícího povrchu. Kontext 101 kryla až $16 \mathrm{~cm}$ mocná šedá

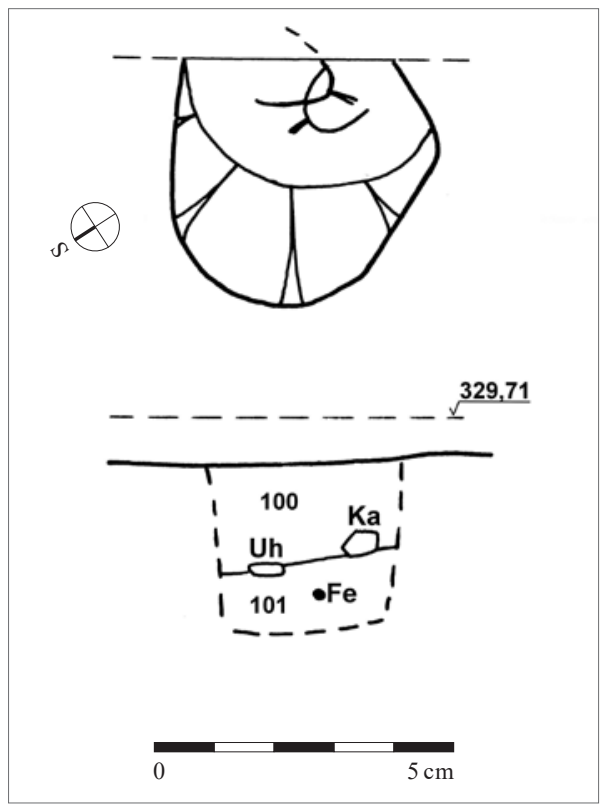

Obr. 11. Zářecká Lhota - Hrádníky. Dokumentace nálezu ostruh. Kresba D. Vích.

Abb. 11. Zářecká Lhota - Hrádníky. Dokumentation der Sporenfunde. Zeichnung D. Vích. 
písčitojílovitá vrstva (kontext 100; obr. 11). V blízkém okolí jsme vedle řady ručně kovaných hřebů identifikovali další kovové předměty, především hroty šípů. Díky údajům uchovávaným v Orlickém muzeu v Chocni navíc víme, že někde zde byly objeveny archeologické nálezy při dobývání pařezů v roce 1942.

Další kumulace kovových předmětů byla zjištěna blízko moderní udírny při samé hraně narušení vzniklého odkopáním terénu při jeho nivelaci v souvislosti se stavbou chaty. Hrana vkopu se nacházela tak blízko kumulaci kovových předmětů, že se nedá vyloučit recentní povrchové narušení celé situace. Nejprve se podařilo objevit kus bronzového (?) prredmětu $\mathrm{v}$ podobě krátké tyčoviny se stopami tavení, z jedné strany opatřené pseudotordováním (obr. 24:2). Spolu s tímto předmětem byly vyzvednuty železné artefakty, polovina podkovy, otočný klíč, dva hřeby a kus prohnutého pásového železa klínovitého příčného průřezu. Pod nimi se objevil další předmět z barevného kovu, po jehož vypreparování se ukázalo, že jde o kř́iž tvořený zuhelnatělým dřevěným jádrem pobitým bronzovými či měděnými plíšky; v jeho okolí se nacházely organické zbytky (obr. 12). Pod křížkem se vedle keramiky objevil hák zhotovený z pásu železa a další prohnutý železný pás klínovitého prŕíčého průřezu (obr. 13). Vše se nacházelo v okrovošedé písčitojílovité vrstvě promísené tvrdě vypálenou mazanicí a keramikou (kontext 102). Po dokumentaci a vyzvednutí popsaných předmětů detektor hlásil další hlouběji uložené železné signály, ty však už byly ponechány na místě, protože při pokračování výkopu formou mikrovrypu by s ohledem na závažnost celé situace hrozila ztráta informací. Pokračování ve výkopu je s ohledem na situování v prostoru ohroženém výkopem pro udírnu a následnou erozí více než žádoucí, musí však již mít formu archeologické sondy.

\section{Movité nálezy z areálu hradu}

Vedle nemovitých nálezů, jejichž poznání se, pokud pomineme situace zjištěné při detektorovém průzkumu, v zásadě omezuje na pozorování reliéfních tvarů, představují movité nálezy při absenci písemných pramenů hlavní zdroj informací o historii lokality.

Důležitou kolekci tvoří artefakty uchovávané v Orlickém muzeu v Chocni získané $\mathrm{v}$ různé době a za různých okolností (k tomu Vích 2009, 33). Bohužel, pouze u dvou ostruh $\mathrm{s}$ jistotou víme, že pocházejí z areálu hradu, ostatní nálezy jsou lokalizovány pouze jako

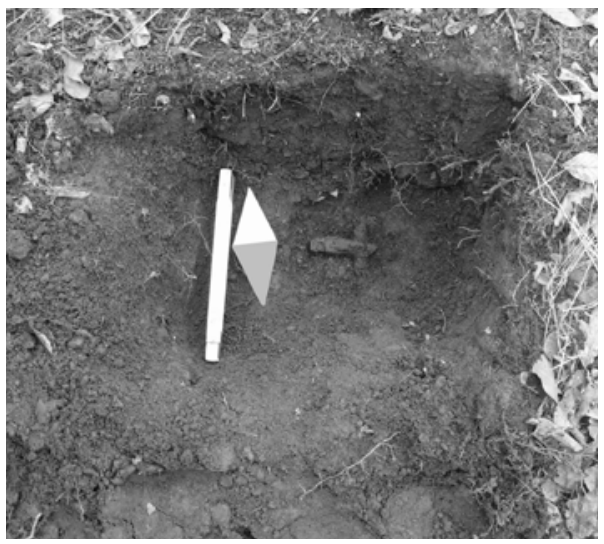

Obr. 12. Zářecká Lhota - Hrádníky. Kř́ž in situ. Foto D. Vích, 25. 2. 2015.

Abb. 12. Zářecká Lhota - Hrádníky. Kreuz in situ. Foto D. Vích, 25. 2. 2015.

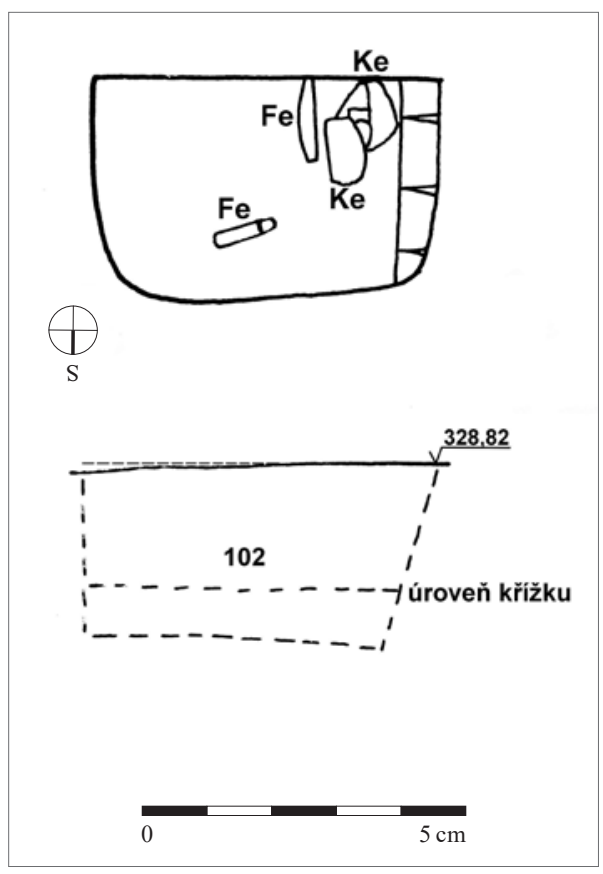

Obr. 13. Zářecká Lhota - Hrádníky. Dokumentace nálezů pod křížem. Kresba D. Vích.

Abb. 13. Zářecká Lhota - Hrádníky. Dokumentation der Funde unterhalb des Kreuzes. Zeichnung D. Vích. 
„Hrádníky“, i když přímá souvislost vrcholně středověké keramiky s hradem je prakticky jistá (výběr na obr. 14, podle Vích 2009). To se bohužel nedá říci o hrotech šípů, které mohou pocházet z širšího okolí a s vlastním hradem nemusí príímo souviset.
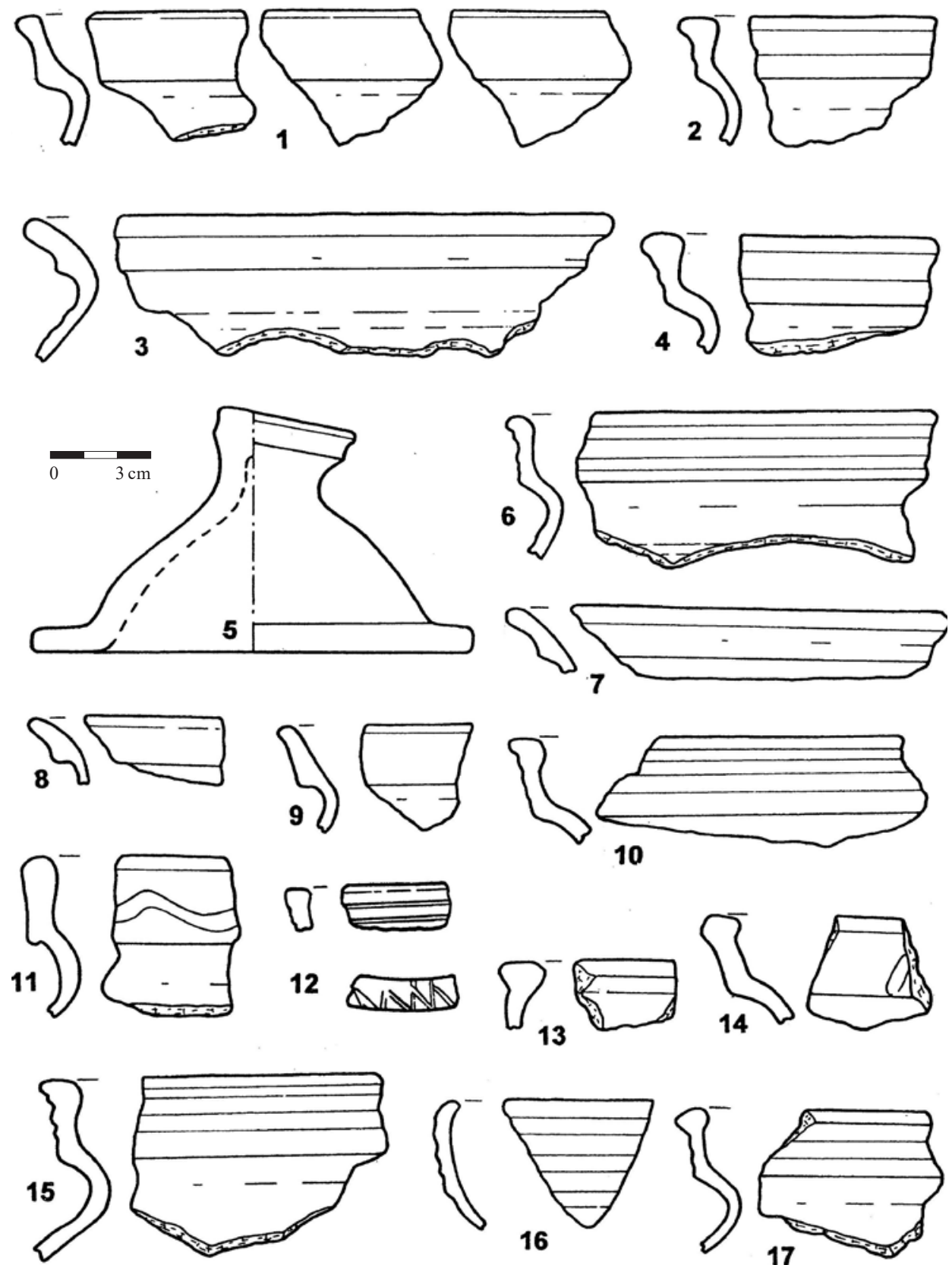

Obr. 14. Zářecká Lhota - Hrádníky. Nálezy keramiky z hradu uložené v Orlickém muzeu v Chocni. Podle Vích 2009, výběr, upraveno.

Abb. 14. Zářecká Lhota - Hrádníky. Im Museum des Adlergebirges in Choceň aufbewahrte Keramikfunde von der Burg. Nach Vích 2009, Auswahl, bearbeitet. 


\subsection{Keramika}

Vedle vrcholně středověké keramiky se v Orlickém muzeu v Chocni nachází také nečetné zlomky z mladší doby hradištní, dále esovitá bronzová záušnice velkého průměru a polovina další (Vích 2009, obr. 73:1-6), jejichž přítomnost bude souviset spíše s plochou pravěkého hradiště. Kolekci keramiky z choceňského muzea doplňují střepy sbírané nedávno v rámci projektové výuky a keramické zlomky získané při detektorové prospekci (obr. 15).

Keramické zboží můžeme rozdělit do dvou hlavních skupin. První skupinu tvoří světlé šedavě bílé až narůžovělé zboží s jemným ostřivem opatřené obvykle vývalkovitou šroubovicí, nezř́idka s výskytem červeného malování. Mnohem častěji se setkáváme s keramikou druhé skupiny hotovenou ještě v duchu hradištní tradice. Tvoří ji redukčně pálené zboží šedých až hnědavých odstínů s výrazným písčitým ostřivem a příměsí slídy opatřené rytou šroubovicí. Méně výrazně vystupuje oxidačně pálená keramika červených odstínů s písčitým ostřivem. Vzácně se vyskytne i střep s prríměsí grafitu ve hmotě.
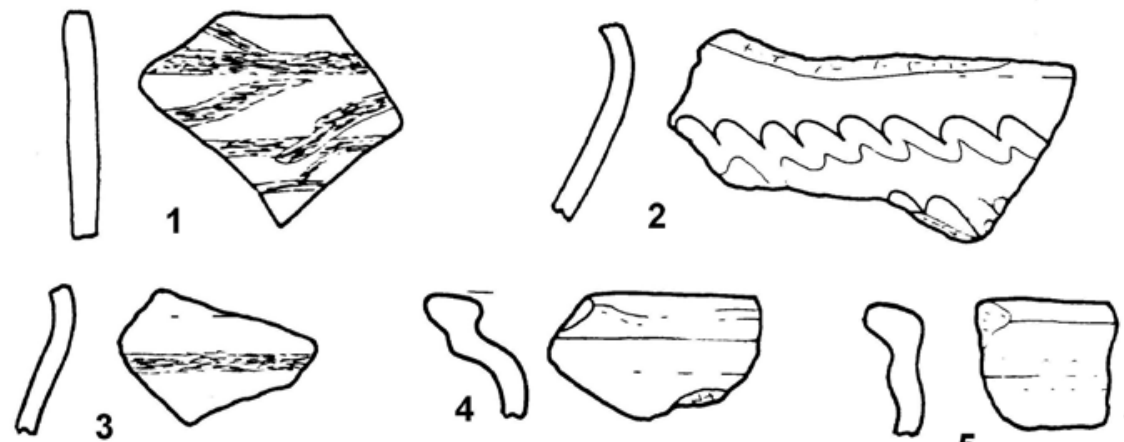

5
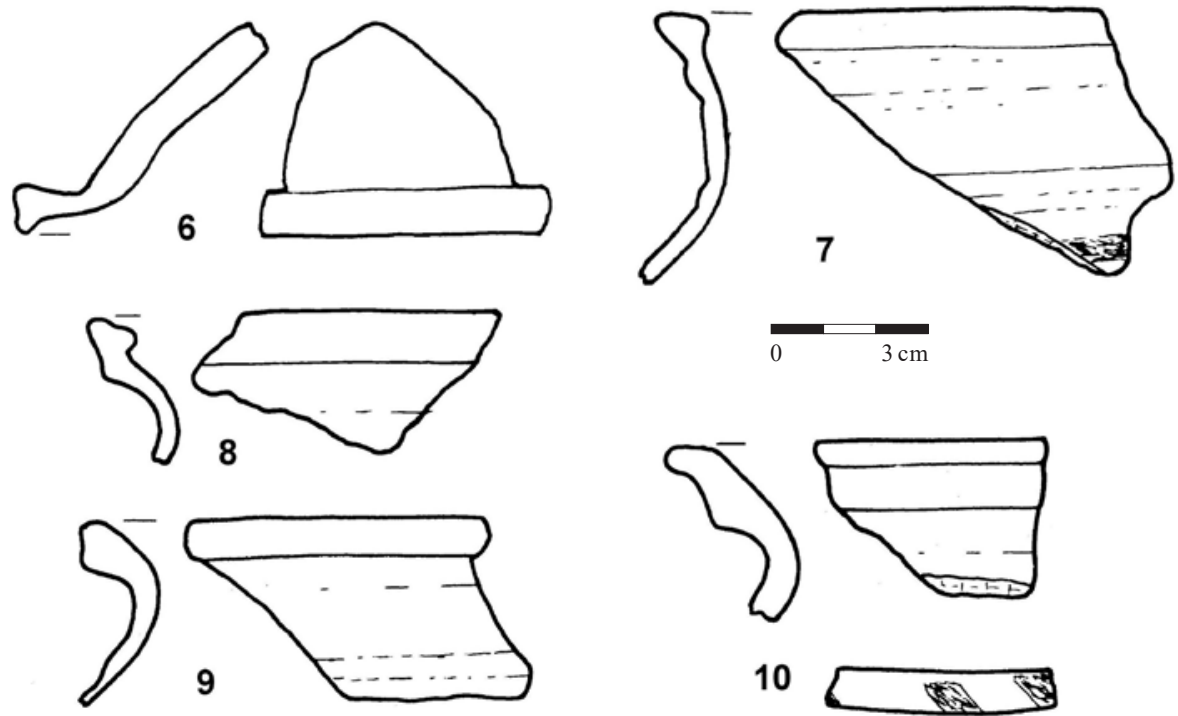

Obr. 15. Zářecká Lhota - Hrádníky. Nálezy keramiky z hradu. 1-4 - keramika získaná sběrem v rámci projektové výuky ZŠ Svatopluka Čecha v Chocni; 5-6 - z lesní humusové vrstvy v místě koncentrace stř́ibrných slitků; 7 - hromadný nález ostruh, vrstva č. 101; 8-10 - hromadný nález s ostatkovým křížem, vrstva č. 102.

Abb. 15. Zářecká Lhota - Hrádníky. Keramikfunde von der Burg. 1-4 - Bei einer im Rahmen des Projektunterrichts der Grundschule Svatopluk Čech in Choceň durchgeführten Oberflächenbegehung entdeckte Keramik; 5-6 - aus der Waldhumusschicht an der Stelle mit Silbergussstückkonzentration; 7 - Sporensammelfund, Schicht Nr. 101; 8-10 - Sammelfund mit Reliquienkreuz, Schicht Nr. 102. 
Vedle žlábkování a vývalkovité šroubovice se ojediněle objevuje motiv vlnice, popř. výzdoba na okrajové plošce v podobě promačkávání okrajové plošky či rytí. Dna nesou stopy podsýpky, v jednom případě dokonce se zbytkem značky, pouze u torza zvonovité pokličky zjišt'ujeme odřezávání strunou. Z keramických tvarů se nejčastěji vyskytují hrnce nesoucí okraj v podobě nepravého okruží, dále pak pokličky. Jedním kusem máme zastoupen okraj jiné nádoby, patrně džbánu (obr. 15:7) a mísy (obr. 14:13).

Celkově působí keramická produkce zastoupená na hradě poměrně homogenním dojmem. Zřetelně zde vystupuje hrnčirrská tradice 13. století aplikovaná na nepravých okružích, ale typy okrajů vysloveně 13. století zde již nenacházíme. Časové těžiště souboru tak shledáváme ve starším úseku 14. století, s vyspělým vrcholně středověkým zbožím závěru 14. až 15 . století se nesetkáváme. Soubor se velmi podobá keramice získané v areálu drobné vrcholně středověké fortifikace v k. ú. Lanšperk (Lanšperk 2), kde je ovšem zboží 13. století výrazně zastoupeno i v okrajích s nezanedbatelným podílem grafitové keramiky (Vích 2010, 324, 327, obr. 7).

\subsection{Předměty ze železa}

\section{Stavební kování}

20. petlice, max. $166 \mathrm{~mm}$ ve zkorodovaném stavu, E 0589586, N 5539171, hl. $20 \mathrm{~cm}$, z toho $5 \mathrm{~cm}$ jílovitopísčitá šedá humusová a $15 \mathrm{~cm}$ podložní okrová jílovitopísčitá (obr. 16:4)

46. dveřní kování se závěsným okem se dvěma dochovanými hřeby, přepáleno, $253 \times 150 \times 38$ mm (bez hřebů), E 0589608, N 5539216, hl. 26 cm v šedé humusové písčitojílovité (obr. 16:1)

36. ohnutý hřeb, max. 46 mm, E 0589577, N 5539198, součást hromadného nálezu v kontextu 102 (obr. 17:3)

37. hřeb, max. 78 mm, E 0589577, N 5539198, součást hromadného nálezu v kontextu 102 (obr. 17:4)

40. otočný klíč s kruhovým okem a plným dř́kem, $124 \times 43 \times 10$ mm, E 0589577 , N 5539198, součást hromadného nálezu v kontextu 102 (obr. 17:2)

53. otočný klíč s kruhovým okem a plným dříkem, $146 \times 49 \times 10$ mm, E 0589580, N 5539213, h1. $10 \mathrm{~cm}$ v šedookrové písčitojílovité na hraně vzniklé odkopáním terénu pro stavbu chaty (obr. 17:1)

50. zásuvná část třmenového pružinového zámku, $89 \times 30 \times 29$ mm, E 0589583 , N 5539190 , hl. $23 \mathrm{~cm}$, z toho $5 \mathrm{~cm}$ tmavošedá písčitojílovitá humusová a $18 \mathrm{~cm}$ okrovošedá písčitojílovitá silně promísená tvrdě vypálenou mazanicí s otisky konstrukcí (obr. 16:2)

51. část svorníkového pružinového zámku, $47 \times 24 \times 21 \mathrm{~mm}$, E 0589612, N 5539197, hl. $15 \mathrm{~cm}, \mathrm{z}$ toho $5 \mathrm{~cm}$ šedá humusová písčitojílovitá a $10 \mathrm{~cm}$ šedookrová písčitojílovitá (obr. 16:3)

Kovové předměty související se stavebními konstrukcemi a uzamykacími mechanismy reprezentují především hřeby, z nichž jsme vyzvedli pouze dva, které byly součástí kumulace kovových předmětů zjištěné u udírny (obr. 17:3-4). Jejich souvislost s tímto hromadným nálezem však není jistá, protože může jít o náhodnou příměs. Za samostatnou zmínku stojí kumulace hřebů zjištěná při jižním okraji plošiny sevřené mezi valovitým tělesem a př́íkopem. Kumulace hřebů s největší pravděpodobností souvisí s nějakou lehčí stavbou v tomto prostoru.

Součástí vrcholně středověkých staveb bez ohledu na sociální prostředí jsou petlice, zastoupené zde jedním kusem (č. 20, obr. 16:4), sestávajícím ze dvou osmičkovitých ok a oka s trnem určeným k zapuštění do pevného podkladu. S petlicemi se na vrcholně středověkých lokalitách setkáváme zcela běžně (srov. Krajíc 1991, s terminologií).

Nepochybně zajímavější je masivní kování s okem sloužící jako dveřní závěs - pant. Studovaný dveřní pant zpracoval kováŕ do podoby části podlouhlého oválu ukončeného vybráním v podobě písmene $\mathrm{V}$ (obr. 16:1). Plochu prorážejí čtyři otvory, přičemž ve dvou se dochovaly hřeby. Dveřní panty mají přitom obvykle tvar víceméně stejně širokého pásu s různě tvarovaným ozdobným ukončením, at' již v podobě listu či lilie apod. (Belcredi 1989, 455; Krajíc 2003, 79-80; Měřínský 2007, obr. 58:9), v některých případech je pak konec vidlicovitě rozeklán 

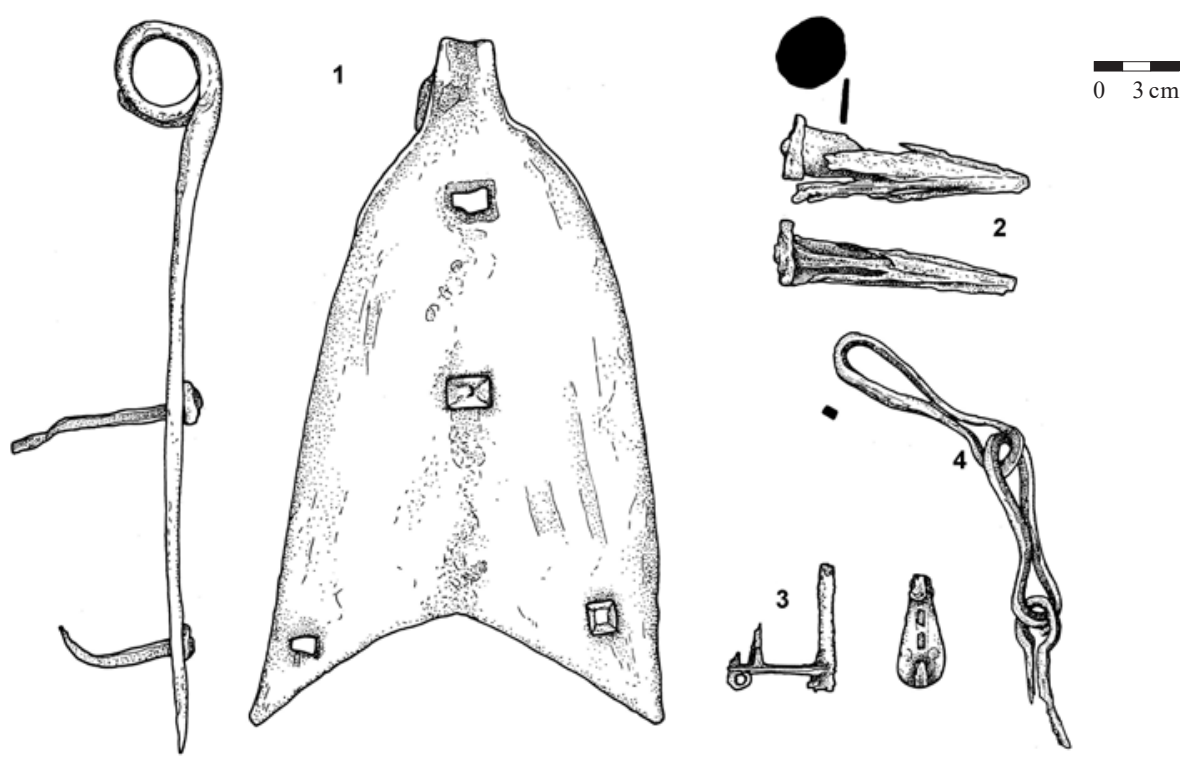

Obr. 16. Zářecká Lhota - Hrádníky. Stavební kování. Abb. 16. Zářecká Lhota - Hrádníky. Baubeschläge.
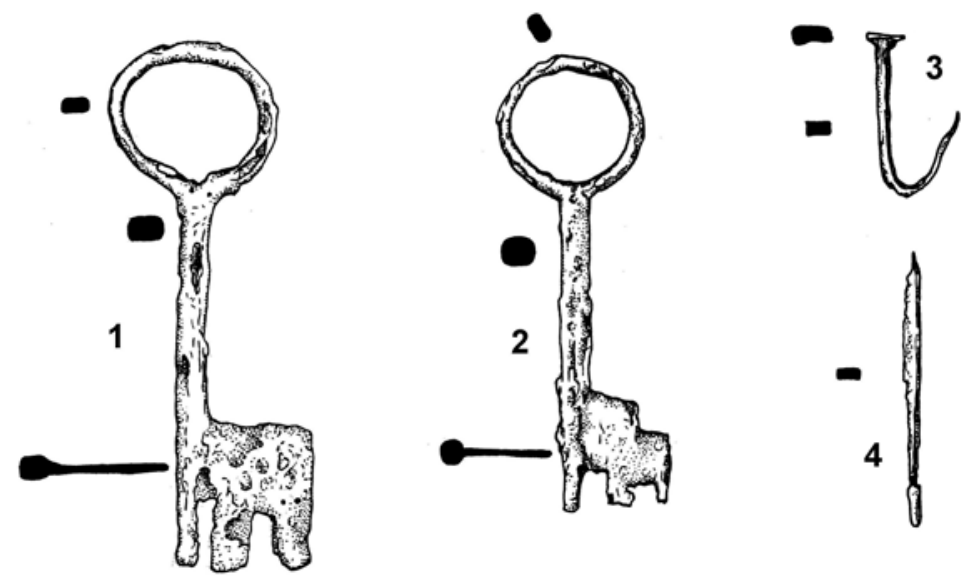

Obr. 17. Zářecká Lhota - Hrádníky. Stavební kování. Abb. 17. Zářecká Lhota - Hrádníky. Baubeschläge.

(Zalužany - Polla 1962, obr. 107:4; Prosetice - Rusó 1986, 413, obr. 3:Q; Sezimovo Ústí - Krajíc 2003, tab. 82: i. č. 50 482), což poněkud připomíná závěs z Hrádník. Nejvěrnější analogii nacházíme v souboru z tvrze v Semonicích (Huml 1967, VI:8, 10-11, 16).

Předmět č. 50 je vyjímatelnou součástí třmenového závěsného zámku (obr. 16:2), respektive závěsného zámku pružinového třmenového (k terminologii především Rasl 1987; Krajíc 1991, 328-332; 2003, 81-87). S těmito zámky se setkáváme zatím spíše jednotlivě v různých lokalitách i sociálním prostředí (město: Sezimovo Ústí - Krajíc 2003, tab. 87: i. č. K50/4183, i. č. 4187; tvrz: Třebovětice - Drnovský 2012, 213, obr. 24:3; hrad: blízký Brandýs nad Orlicí - Vích 2014, obr. 4:1; Sitno - Labuda 1999, 223, obr. 5:4; vesnice: Svinica - Čaplovič 1983, obr. 8:3; Mutějovice - Pleiner 1969, 556, 560, obr. 16). Jde o zámek charakteristický pro celý vrcholný středověk s těžištěm výskytu ve 14.-15. století (Krajíc 1991, obr. 11; jako vývojově nejstarší typ viz Rasl 1987, 150). 
Vyjímatelnou součástí zámku je i předmět č. 51, tentokrát jde však o závěsný zámek svorníkový pružinový (obr. 16:3), který se velmi hojně objevuje především v prostř̌edí opevněných sídel (např. Semonice - Huml 1967, 26, 40, obr. II:8; Tepenec - Burian 1971, 66, tab. 46:1, Nový hrad Merta 1974; Melice - Unger 1974, 197, obr. 2:10; Vizmburk - Hejna 1983, 494, obr. 3:6; Koštál a kol. 2013, 137, tab. 56:4; Liptovský hrad - Hanuliak 1983, 483, Tab. V; Lelekovice - Unger 1999, 87, obr. 91:1-2, 7; Rokštejn - Měŕínský 2007, obr. 59:11-17), ale i v prostředí církevním (Burian 1960, 210, obr. 77; 1973, tab. 58:6), venkovském (Konůvky - Šauerová 1980; Topolany - Unger 1984, 86, obr. 14:9; Chl'aba - Hanuliak 1986, 476, obr. 5; Praha-Hostavice - Richterová 1996, 298 , obr. 19:84; Spindelbach - Hylmarová-Klír-Černá 2013, 578, obr. 5:10, 14) a městském (Hradec Králové - Richter-Vokolek 1995, tab. 118:20; Banská Štiavnica - Labuda 2000, 16, obr. 6:7; Sezimovo Ústí - Krajíc 2003, 82-83, tab. 87). Objevují se již od druhé poloviny 13. století (Richter 1982, 178, obr. 7:3; Krajíc 1991, 331; 2003, 82; Unger 1981, obr. 3:1; 1989, tab. 25:7584; 1994, 24 , obr. 17:6), běžné se ale stávají až ve 14.-15. století (Hanuliak 1983, 483; Krajíc 1991, 331; 2003, 82).

Z klíčů disponujeme dvěma typologicky shodnými exempláři, přičemž v obou prŕípadech jde o reprezentanty klíčů otočných (obr. 17:1-2). Klíče s kruhovým okem a plným dříkem náleží k typu VIII podle R. Krajíce (1991, 332-333, obr. 9; 2003, 92, obr. 91) s výskytem ve 13.-14. století (popř. dříve). Postupem času pak převládly klíče s dutým dříkem a prostým kruhovým okem, až nakonec je kruhové oko postupně opatřováno prolamovanou výzdobou (Klíma 1980, obr. 41; Slivka 1981, 238-239; Krajíc 1991, obr. 10; 2003, 93, obr. 90).

\section{Zemědělské nářadí}

6. motyka se zbytky dřeva v oku, $316 \times 57 \times 54 \mathrm{~mm}$, E 0589607 , N 5539223, v hloubce $50 \mathrm{~cm}, \mathrm{z}$ toho $25 \mathrm{~cm}$ tvoří šedá humusová vrstva a $25 \mathrm{~cm}$ štěrkopísek, šikmo ostřím po svahu (obr. 18:1)

34. zub z bran, $166 \times 17 \times 17 \mathrm{~mm}, \mathrm{E} 0589598$, N 5539186, hl. $18 \mathrm{~cm}$ na rozhraní šedé humusové jílovitopísčité a šedookrové písčité (obr. 18:2)

Dva předměty patří $\mathrm{k}$ zástupcům zemědělského nářadí, i když motyka mohla teoreticky souviset i s řemeslnou činností, při níž se pracovalo s hlínou.

Zatímco hrotitý předmět s naseknutými hranami v horní nejširší části artefaktu (obr. 18:2) představuje hřeb z bran s nepřeberným množstvím analogií (Krajíc 2003, 135-136), nepoměrně vzácněji, už jenom s ohledem k množství použitého kovu, se vyskytuje masivní motyka nalezená na severním svahu hradu. Dlouhá úzká pracovní část nástroje se směrem k ostř́ rozšiřuje, spodní část oka nese př́íný výběžek (obr. 18:1). To ji řadí k typu Ic podle R. Krajíce $(2003,137)$ s podobnými či přesnými analogiemi v Jaroměři (Hejna 1959, 113, obr. 51:4), Zalužanech (Polla 1962, 125, obr. 101:7b), Semonicích (Huml 1967, II:3), Dolném Poltáru (z hrobu, Hrubec 1971, 72, obr. 3:8), Sezimově Ústí (Drda 1978, I:7-10; Krajíc 2003, tab. 110:K08/2911, K06/2910, K07/2912, 111:50996), Mstěnicích (Nekuda 1985, 129), Mohelnici (Goš 1986, 195, obr. 1:11) a Konůvkách (Měchurová 1997, 88, tab. LXX) s dlouhým časovým výskytem.

\section{Výstroj koně a jezdce}

7. ostruha s parabolicky prohnutými rameny s odlomenými úchyty a jedním ramenem krátké vidlice, E 0589608 , N 5539224, hl. $10 \mathrm{~cm}$, z toho $5 \mathrm{~cm}$ šedá humusová písčitojílovitá a $5 \mathrm{~cm}$ okrovošedá písčitojílovitá (obr. 20:5)

9. přezka s dochovaným trnem, E 0589618, N 5539229, hl. $30 \mathrm{~cm}$ z toho $14 \mathrm{~cm}$ šedá humusová písčitojílovitá a $16 \mathrm{~cm}$ okrová jílovitá (obr. 20:3)

28. přezka z ostruhy, $39 \times 29 \times 8$ mm, E 0589602, N 5539173, součást hromadného nálezu v kontextu 101 (obr. 19:2)

29. přezka z ostruhy, $44 \times 34 \times 11$ mm, E 0589602 , N 5539173, součást hromadného nálezu v kontextu 101 (obr. 19:3)

30. část upínacího zařízení ostruhy, $29 \times 24 \times 10$ mm, E 0589602, N 5539173, součást hromadného nálezu v kontextu 101 (obr. 19:5) 

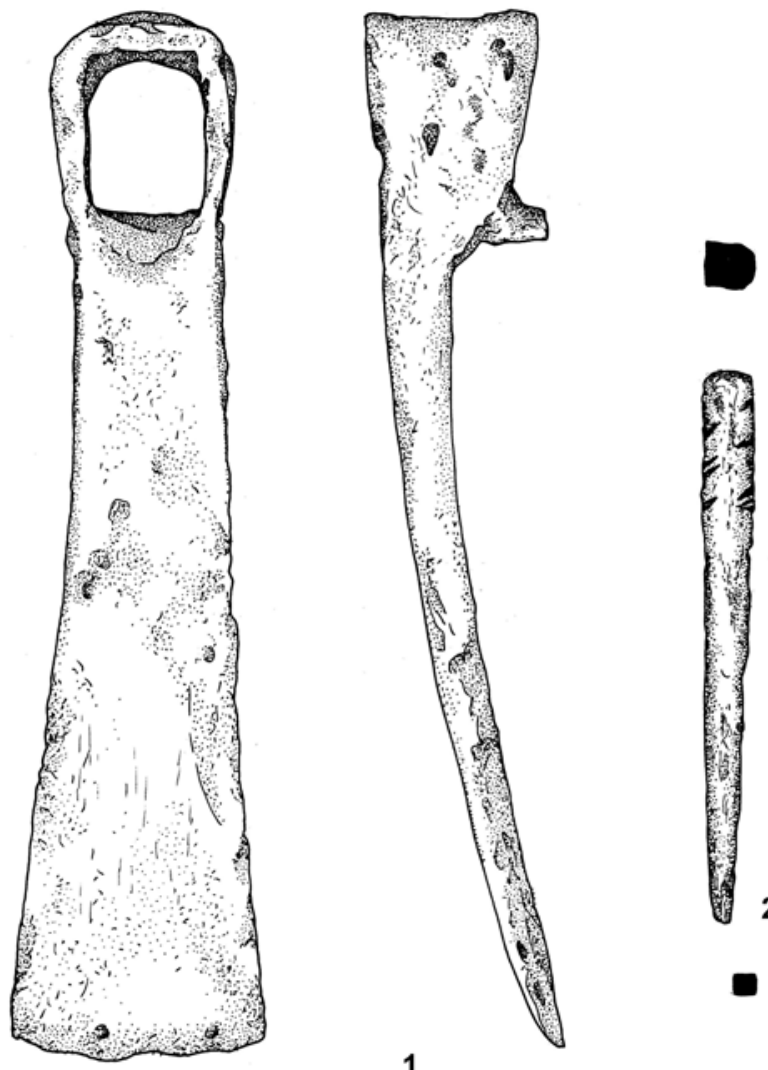

1

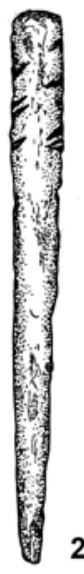

Obr. 18. Zářecká Lhota - Hrádníky. Zemědělské nářadí.

Abb. 18. Zářecká Lhota - Hrádníky. Landwirtschaftliche Geräte.

31. část upínacího mechanismu ostruhy v podobě kolečka, d 24 mm, v. 5 mm, E 0589602 , N 5539173, součást hromadného nálezu v kontextu 101 (obr. 19:4)

32. ostruha s upínacím zařízením $v$ jednoduchých kruhových úchytech na parabolicky prohnutých ramenech, v krátké vidlici chybí kolečko, $128 \times 109 \times 51$ mm, E 0589602, N 5539173, součást hromadného nálezu v kontextu 101 (obr. 11; 19:6)

33. ostruha $\mathrm{s}$ upínacím zařízením $\mathrm{v}$ jednoduchých kruhových úchytech na parabolicky prohnutých ramenech, s kolečkem v krátké vidlici, $167 \times 117 \times 37$ mm, E 0589602, N 5539173, součást hromadného nálezu v kontextu 101 (obr. 11; 19:1)

42. rámeček přezky, $65 \times 48 \times 6 \mathrm{~mm}$, E 0589577 , N 5539198, součást hromadného nálezu v kontextu 102 (obr. 20:4)

48. ostruha s parabolicky prohnutými rameny ukončenými jednoduchými kruhovými úchyty, s krátkou vidlicí bez kolečka, přepáleno, max. 140 mm, E 0589583, N 5539198, hl. 13 cm, z toho $6 \mathrm{~cm}$ šedá humusová písčitojílovitá a $7 \mathrm{~cm}$ okrovošedá silně promísená s tvrdě vypálenou mazanicí s otisky konstrukcí, nalezeno spolu s č. 47 (obr. 20:1)

12. necelá polovina podkovy, $142 \times 38 \times 37 \mathrm{~mm}$, E $0589590, \mathrm{~N} 5539172, \mathrm{hl} .20 \mathrm{~cm}$, z toho $11 \mathrm{~cm}$ šedá písčitojílovitá humusová, $9 \mathrm{~cm}$ okrové písčitojílovité podloží (obr. 21:5)

13. polovina podkovy bez hmatce se zbytky hřebu, $127 \times 36 \times 26 \mathrm{~mm}$, E 0589617 , N 5539207, hl. 6 cm v šedé humusové písčitojílovité (obr. 21:3) 
26. celá podkova bez hmatce, $107 \times 116 \times 224 \mathrm{~mm}$, E 0589604, N 5539195, hl. $14 \mathrm{~cm} \mathrm{v} \mathrm{hu-}$ musové šedé píčitojílovité (obr. 21:1)

39. polovina podkovy, $108 \times 28 \times 14 \mathrm{~mm}$, E 0589577 , N 5539198, součást hromadného nálezu v kontextu 102 (obr. 21:4)

49. část ramene podkovy, $121 \times 32 \times 28 \mathrm{~mm}$, E 0589582 , N 5539179, hl. $26 \mathrm{~cm}$, z toho $16 \mathrm{~cm}$ černošedá humusová písčitojílovitá a $10 \mathrm{~cm}$ podložní okrová jílovitá (obr. 21:2)

35. celé dvoudílné stíhlové udidlo, 120 mm v zkorodovaném stavu, E 0589605, N 5539196, hl. $22 \mathrm{~cm}, \mathrm{z}$ toho $6 \mathrm{~cm}$ šedá humusová jílovitopísčitá a $16 \mathrm{~cm}$ šedookrová jílovitopísčitá, pod kořeny habru (obr. 20:2)

Ostruhy představují důležitou, totiž chronologicky relativně citlivou složku celé kolekce. $Z$ vlastního areálu fortifikace dnes s větší či menší jistotou fyzicky disponujeme celkem šesti kusy. Ve dvou případech jde o nálezy staršího data, a to o již zmíněnou ostruhu nalezenou v souvislosti s výkopem pařezů (Vích 2009, 33, obr. 70:3) a další dva exempláře objevené v sou-
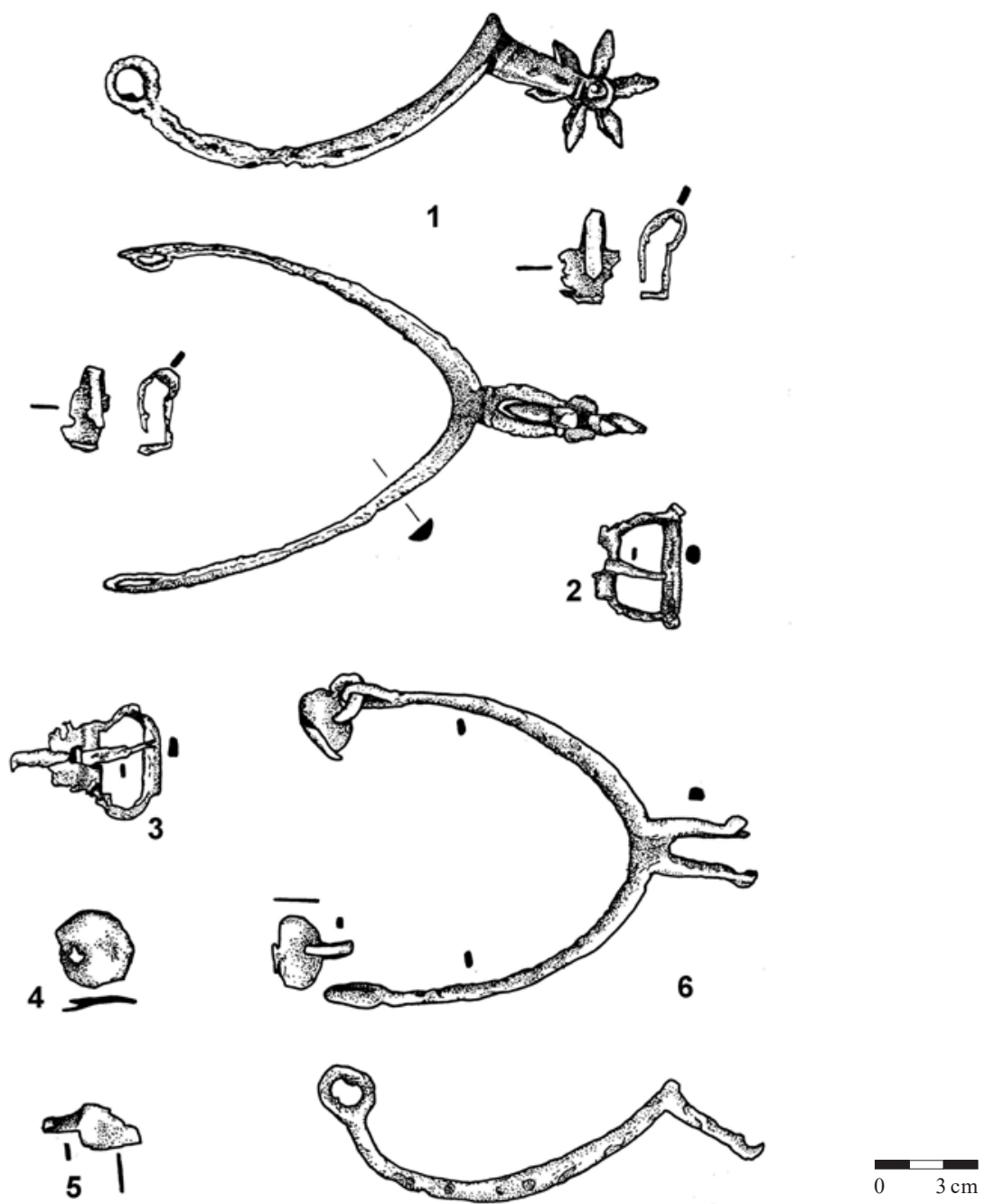

Obr. 19. Zářecká Lhota - Hrádníky. Výstroj koně a jezdce - ostruhy (hromadný nález ostruh). Abb. 19. Zářecká Lhota - Hrádníky. Pferd- und Reiterausrüstung - Sporen (Sporenhortfund). 
vislosti s terénními úpravami při stavbě chaty, z nichž dokážeme v muzejních sbírkách s určitou mírou pravděpodobnosti identifikovat pouze jediný kus (Vích 2009, 33, obr. 70:8, ke ztotožnění exempláře bez nálezových okolností s ostruhou z Hrádník došlo na základě nekvalitní fotografie), a dále pak o čtyři exempláře (či jejich torza) vyzvednuté při nových průzkumech v letech 2009-2015. Obyvatelé hradu používali ve všech případech jediný typ ostruhy s krátkou vidlicí a parabolicky prohnutými rameny ukončenými symetricky nasazenými jednoduchými kruhovými úchyty, což je řadí k typu C (Ruttkay 1976, Abb. 72), popř. typu III (Wachowski 1984, 54, Ryc. 36) s výskytem od 13. století (tamtéž, 54) až po starší úsek 14. století (Ruttkay 1976, 350-352; Drobný 1995, 51; Krajíc 2003, 126; Koóšová 2004, 430-536, tab. 1). Ke stejnému typu se s největší pravděpodobností dle krátké vidlice hlásí i poškozený exemplář č. 7 (obr. 20:5).

Uložení dvou ostruh (z nichž jedna ovšem postrádá kolečko, a tudíž ji nemůžeme považovat za funkční, pokud k dislokaci kolečka nedošlo při archeologizaci situace) objevených pohromadě (obr. 11; 19) nepatří v hradním prostředí $\mathrm{k}$ běžným situacím, a to ani při použití detekční techniky. Větší počet kovových předmětů v tomto prostoru byl objeven již roku 1942. Snad i s ohledem na velkou koncentraci železných hřebů zde můžeme spekulovat o existenci lehčí dřevohlinité stavby sloužící jako místo uložení železných předmětů, více jistoty ovšem může přinést pouze archeologický odkryv.
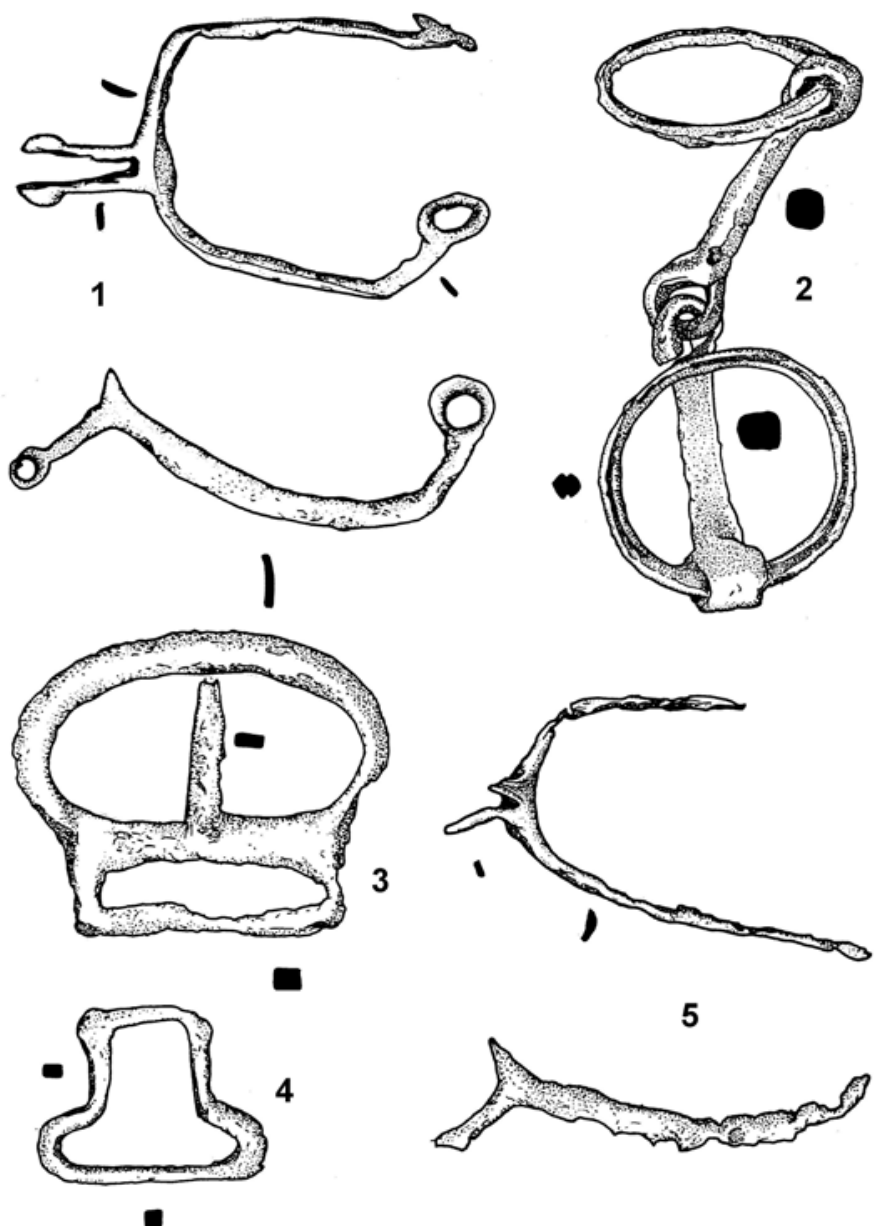

5

Obr. 20. Zářecká Lhota - Hrádníky. Výstroj koně a jezdce.

Abb. 20. Zářecká Lhota - Hrádníky. Pferd- und Reiterausrüstung. 

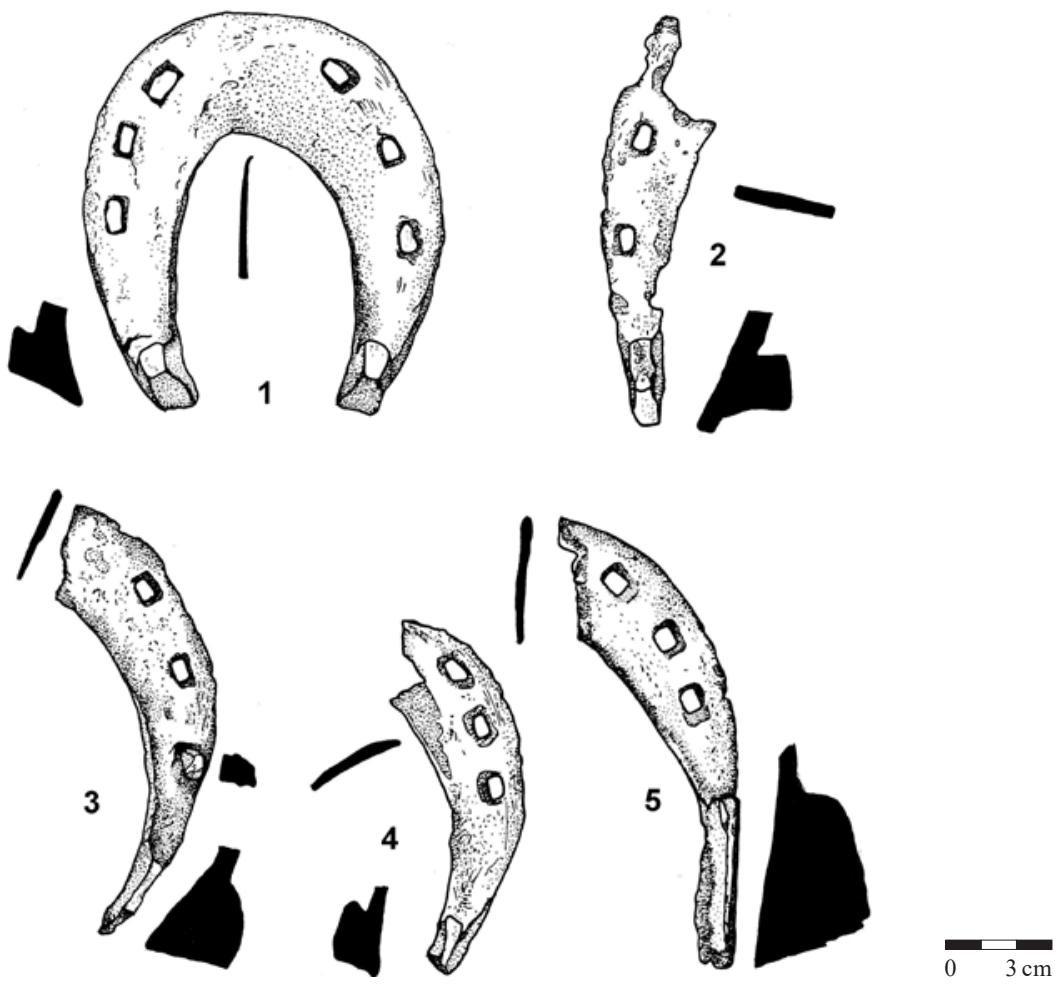

Obr. 21. Zářecká Lhota - Hrádníky. Výstroj koně a jezdce - podkovy.

Abb. 21. Zářecká Lhota - Hrádníky. Pferd- und Reiterausrüstung-Hufeisen.

Podstatně menší vypovídací schopnost mají z chronologického hlediska další předměty. Jde o dvě přezky z koňského postroje (obr. 20:3-4) známé z řady blízkých i vzdálených analogií, např. ze Siónu (Janská 1963, 246, obr. 75), Pfaffenschlagu (Nekuda 1975, 138, obr. 139:3), Děvína (Polla-Egyházy-Jurovská 1975, 108, obr. 21:7), Týřova (Durdík 1976, tab. IX:27), Vizmburku (Hejna 1983, 496, obr. 5:1-2), Tábora (Drda 1983, 282, obr. 6:2), Prahy-Záběhlic (Lochmann 1985, 196, obr. 9:4; Rábí (Durdík 1989, obr. 4:19), Vildštejna (Durdík-Frolík 1993, 58, obr. 17:9), Branče-Vel'ké Vsi (Ruttkay-Cheben-Ruttkayová 1994, 231, obr. 9:5), Konůvek (Měchurová 1995, 170-171, tab. VI), Mstěnic (Nekuda-Nekuda 1997, obr. 146:a), Lichnice (Frolík 2002, obr. 4:11), Sezimova Ústí (Krajíc 2003, 128, tab. 107:11745, 50420, 8517) a Rumberku (ČernáStaněk-Zůbek 2012, obr. 30:103/5). O delším přežívání těchto předmětů svědčí např. nález přezky z hrobu bojovníků padlých v bitvě na Bílé hoře (Havel 1980, 227, obr. 2:9-10).

Všech pět dochovaných podkov nese rozšířenou střední část, která se směrem k ramenům opatřeným ozuby zužuje, ani v jednom případě nejsou otvory pro hřeby zapuštěny do žlábku. V kompletním stavu se dochoval jediný kus č. 26 postrádající hmatec, nesoucí po třech jednoduše proražených otvorech pro hřeby $\mathrm{v}$ každém rameni (obr. 21:1). Tvar ozubů ho řadí $\mathrm{k}$ typu $4 \mathrm{~d}$ podle R. Krajíce, který se vyskytuje od počátku 14. století (Krajíc 2003, 102-109, obr. 95-96). Ostatní podkovy dochované přibližně z jedné poloviny více či méně náleží ke Krajícovu typu $6 \mathrm{c}-6 \mathrm{~d}$ s podobným datováním. V klasifikaci J. Kaźmierczyka náleží různým variantám skupiny VI (především VI/1, VI/2) datované od druhé poloviny 13. do 15. století (Kaźmierczyk 1978, 86-103).

V př́ípadě kompletně dochovaného udidla (obr. 20:2) jde o typ II (Měchurová 1984, 276, 267, tab. I; Ruttkay 1976, 357-358), I (Nadolski 1954, 87), respektive o typ 3 (Krajíc 2003, 112), které patří k nejrozšířenějšímu typu udidel s výskytem od střední doby hradištní (Měchurová 1984) se starší tradicí a s využitím hluboko do novověku. 


\section{Militaria}

10. hrot šípu s odlomeným trnem, $62 \times 15 \times 9$ mm, E 0589618, N 5539206, hl. do $15 \mathrm{~cm}$ v šedé humusové písčitojílovité s mazanicí (obr. 22:2)

14. hrot šípu s částečně odlomeným trnem, $74 \times 12 \times 9$ mm, E 0589612, N 5539171, hl. 8 cm v šedé humusové písčitojílovité (obr. 22:3)

21. torzo hrotu šípu s odkorodovaným trnem $56 \times 11 \times 6 \mathrm{~mm}, \mathrm{E} 0589583, \mathrm{~N} 5539170, \mathrm{hl} .20 \mathrm{~cm}$, z toho $6 \mathrm{~cm}$ šedá písčitojílovitá humusová a $14 \mathrm{~cm}$ podložní okrová jílovitopísčitá (obr. 22:7)

24. hrot šípu s odkorodovaným trnem, $64 \times 9 \times 8$ mm, E 0589600, N 5539180, hl. do $15 \mathrm{~cm}$ v humusové šedé písčitojílovité s mazanicí (obr. 22:4)

25. hrot šípu s odkorodovaným trnem, $81 \times 13 \times 10$ mm, E 0589592 , N 5539177, těsně pod povrchem $-3 \mathrm{~cm}$ v okrové písčitojílovité (obr. 22:5)

27. hrot šípu s odkorodovaným trnem, $84 \times 13 \times 10 \mathrm{~mm}$, E 0589594, N 5539184, hrotem kolmo do země s trnem na povrchu pod listím (obr. 22:6)

54. masivní hrot šípu s trnem, $111 \times 15 \times 14$ mm, E 0589595 , N 5539178, hl. 15 cm v tmavošedé humusové písčitojílovité (obr. 22:8)

55. masivní hrot šípu s trnem, $115 \times 16 \times 15$ mm, E $0589586, \mathrm{~N} 5539216$, hl. $17 \mathrm{~cm}, \mathrm{z}$ toho $10 \mathrm{~cm}$ šedá humusová písčitojílovitá a $7 \mathrm{~cm}$ podložní okrová písčitojílovitá (obr. 22:9)

52. čepel dýky výrazně klínovitého příčného průřezu, $214 \times 20 \times 10 \mathrm{~mm}$, E 0589602 , N 5539197, hl. $25 \mathrm{~cm}, \mathrm{z}$ toho $18 \mathrm{~cm}$ šedá humusová písčitojílovitá a $7 \mathrm{~cm}$ okrovošedá písčitojílovitá (obr. 22:1)

Všech osm získaných hrotů šípů náleží $\mathrm{k}$ hrotům s trnem, přičemž dva z nich představují masivnější exempláře. Jde o zástupce skupiny A 1b podle T. Durdíka (1972), popř. A, typu II v pojetí R. Krajíce s datací do druhé poloviny 13. století a první poloviny 14. století (Krajíc 2003, 186, obr. 150, 153), skupině B typu 11 v pojetí A. Ruttkaye (1976, Abb. 54) s datací do 13. nebo počátku 14. století (Ruttkay 1976, 331, Abb. 54) či D 2-4, popř. D 2-5, s datováním do 10.-15. století (Zimmermann 2000, 75-76, Tafel 24, 25).
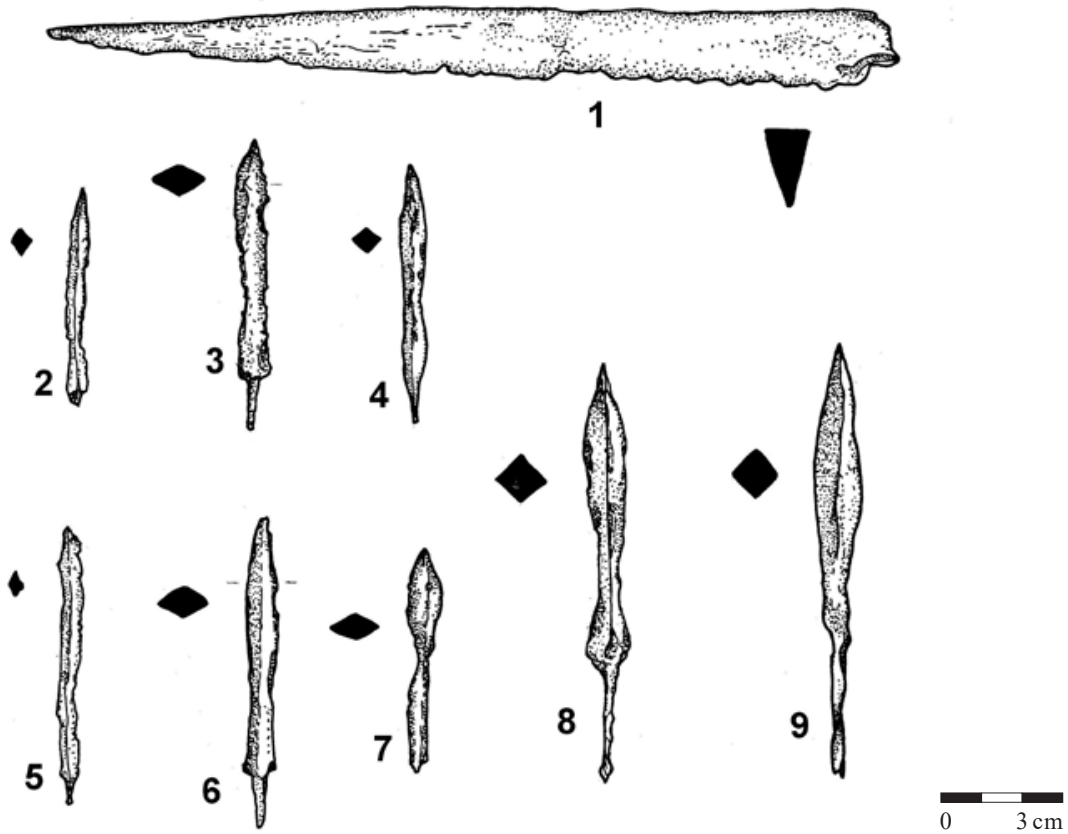

Obr. 22. Zářecká Lhota - Hrádníky. Militaria. Abb. 22. Zářecká Lhota-Hrádníky. Militaria. 
K militariím řadím i čepel s výrazně trojúhelníkovitým př́ičným průřezem (obr. 22:1). Výrazné zesílení hřbetu činí využití této čepele v běžném životě méně pravděpodobným, vhodnější uplatnění by kvůli snazšímu průniku ochrannou zbrojí mohl najít ve sfére vojenské. S určitou rezervou (neznáme způsob upevnění rukojeti) můžeme předmět klasifikovat jako čepel dýky (Žákovský 2014, 202; Žákovský-Hošek 2015, 221-223).

\section{Předměty osobni potřeby}

8. rámeček přezky, $59 \times 58 \times 9 \mathrm{~mm}, \mathrm{E} 0589601, \mathrm{~N} 5539221$, hl. $30 \mathrm{~cm}, \mathrm{z}$ toho $24 \mathrm{~cm}$ humusová šedá písčitojílovitá, 6 cm šedookrová jílovitá (obr. 23:2)

11. nůž $\mathrm{s}$ řapem pro obložení stř̌enkou $\mathrm{z}$ organické hmoty s jedním dochovaným měděným nýtem, $297 \times 25 \times 6$ mm, E 059624, N 5539225, hl. 10 cm na rozhraní šedé humusové písčitojílovité vrstvy a okrového podloží (obr. 23:1)

Poněkud překvapivě disponujeme pouze dvěma noži, přestože patřily k nejzákladnějšímu vybavení vrcholně středověkého člověka (Holtmann 1993, 28-29), přičemž čepel výrazného klínovitého příčného průřezu řadím k militariím (obr. 22:1). Rámeček přezky (obr. 23:2) nelze blíže chronologicky ani funkčně určit - může jít o součást výstroje koně a jezdce, stejně tak může souviset s osobním vybavením.

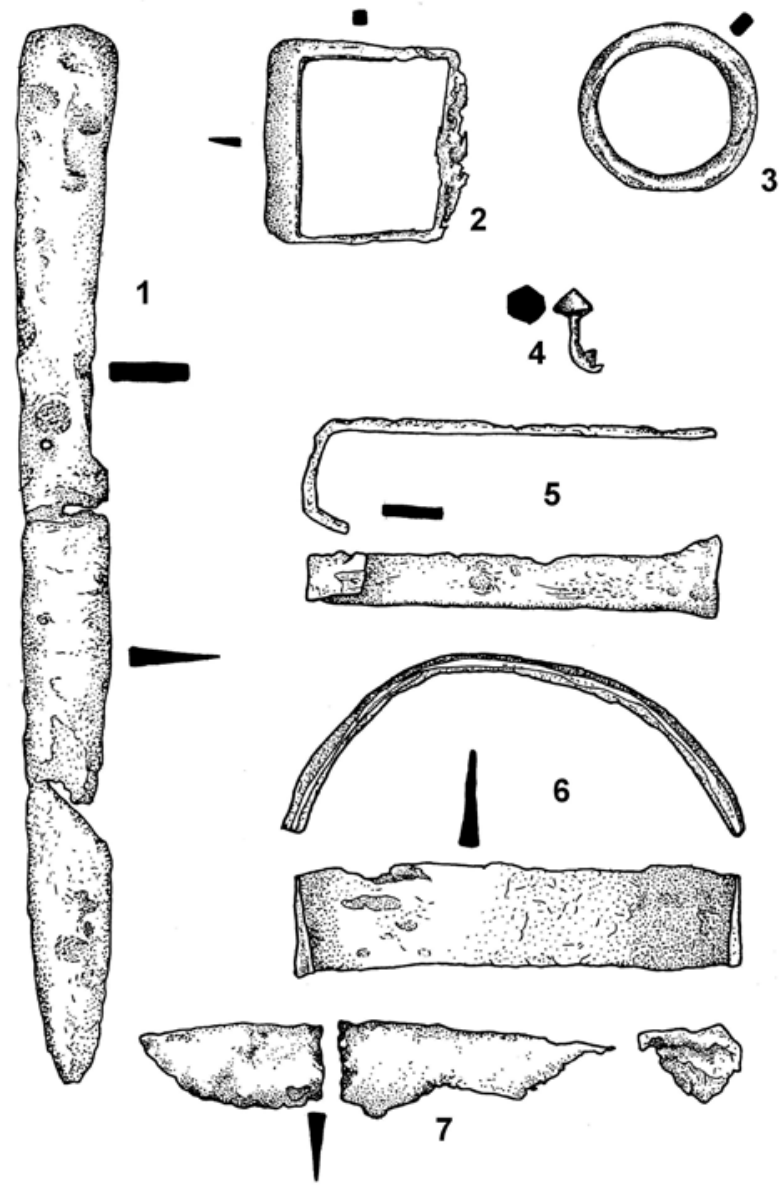

Obr. 23. Zářecká Lhota - Hrádníky. Předměty osobní potřeby a neurčené artefakty.

Abb. 23. Zářecká Lhota - Hrádníky. Gegenstände des persönlichen Bedarfs und unbestimmte Artefakte. 


\section{Ostatni}

15. artefakt s kuželovitým trnem, max. 26 mm, E $0589617, \mathrm{~N} 5539209, \mathrm{hl} .30 \mathrm{~cm}$, z toho $24 \mathrm{~cm}$ šedá humusová písčitojílovitá s mazanicí, 6 cm šedookrová písčitohlinitá s mazanicí (obr. 23:4)

38. prohnutý pás klínovitého příčného průřezu, $133 \times 28 \times 7$ mm, E 0589577, N 5539198, součást hromadného nálezu v kontextu 102 (obr. 23:6)

43. hák z pásoviny, $123 \times 25 \times 36 \mathrm{~mm}$, E 0589577 , N 5539198, součást hromadného nálezu v kontextu 102 (obr. 23:5)

44. zahrocená prohnutá pásovina klínovitého prŕíčného průřezu, $125 \times 30 \times 9 \mathrm{~mm}$, E 0589577, N 5539198, součást hromadného nálezu v kontextu 102 (obr. 23:7)

47. jednoduchý kruh, d 50 mm, v. 5 mm, E 0589583, N 5539198, hl. $13 \mathrm{~cm}$, z toho $6 \mathrm{~cm}$ šedá humusová písčitojílovitá a $7 \mathrm{~cm}$ okrovošedá silně promísená s tvrdě vypálenou mazanicí s otisky konstrukcí, nalezeno spolu s č. 48 (obr. 23:3)

Celkem pět artefaktů neumožňuje spolehlivé funkční určení. Jde o tři kusy železné pásoviny, předmět s kuželovitým trnem a kroužek s možností širokého použití nalezený spolu s ostruhou v jižním valovitém útvaru v areálu fortifikace.

\subsection{Předměty z barevných kovi̊}

22. zlomek ramene skládacích vážek, $57 \times 8 \times 7,5$ mm, E 0589602, N 5539192, pohozeno (?) volně pod listím na povrchu (obr. 24:4)

41. hranol ze slitiny mědi, patrně bronzu, oble čtvercového příčného průřezu, z jedné strany s pseudotordováním, jeden konec výrazně nataven, 57 × $25 \times 24$ mm, E 0589577, N 5539198, součást hromadného nálezu v kontextu 102 (obr. 24:2)

45. torzo ostatkového dvouramenného kříže zhotoveného z bronzových plíšků s plechovým korpusem na zuhelnatělém dřevě, $131 \times 69 \times 20$ mm, E 0589577 , N 5539198, součást hromadného nálezu v kontextu 102 (obr. 12, 25)

60. bronzové kování, $43 \times 16 \times 3,5 \mathrm{~mm}$, E 0589568 , N 5539171, hl. $10 \mathrm{~cm}$ v šedé jílovité splachové vrstvě (obr. 24:3)

57. částečně přepálený měděný plech rozlomený na dvě části, 150 a $46 \mathrm{~mm}$, E 0589605 , N 5539202, hl. 40 cm v šedočerné písčitojílovité s kameny a tvrdě vypálenou mazanicí (obr. 24:1)

Tyčinkovitý předmět ukončený charakteristickým hranolem s okosenými hranami a okem nepochybně představuje koncový zlomek ramen skládacích vážek (obr. 24:4). Zatímco M. Richter, který se těmto předmětům u nás věnoval jako první, disponoval pouze několika kusy (Richter 1963; podobně pro moravské nálezy Michna 1979), počátkem třetího tisíciletí M. Ježek $(2002,453)$ registruje již více než dvacítku skládacích vážek či jejich částí, o několik let později J. Doležel napočítal již téměř tři desítky kusů $(2007,153)$. Časově se jejich výskyt váže k 13. století, od první poloviny 14. století četnost jejich výskytu zřetelně klesá. Ve významné míře se objevují v situacích s vazbou na místní i dálkový obchod a v oblasti dobových horních revírů. Nejčastěji se s nimi proto setkáváme $\mathrm{v}$ městském prostředí, v hradním prostředí se objevují nepoměrně vzácněji (Ježek 2002, 453-454; Doležel 2007, 147-148). S ohledem na dochování pouze části ramene vážek je u kusu z Hrádník zevrubná typologická analýza problematická. Vzhledem ke krychličkovitému zesílení s okosenými hranami na konci ramene jde s největší pravděpodobností o typ 8 , s nímž se v českých zemích setkáváme nejčastěji. Teoreticky však nemůžeme vyloučit ani př́íslušnost ke staršímu typu 7 odlišujícímu se druhým zesílením blíže ke středu vážek, popř. již čistě teoreticky k heterogennímu typu 10 (Steuer 1997, 29-33, 172, Abb. 117).

Drobné lité bronzové kováníčko (obr. 24:3) nalezené ve splachu na jižním svahu se svým stylem hlásí do 13. století, popř. do staršího úseku věku následujícího. Velmi podobný předmět datovaný do 13. století pochází z Hradišt'ka u Davle (Richter 1982, obr. 132:14). 
Kříž s dřevěným zuhelnatělým jádrem z buku a dubu (určil Jan Novák z Laboratoře archeobotaniky a paleoekologie Jihočeské univerzity v Českých Budějovicích) je dochován pouze torzovitě (obr. 25), což lze hypoteticky vysvětlit narušením situace odkopáním terénu při stavbě chaty ve 30 . letech minulého století. V bezprostředním okolí předmětu a přikorodované na jeho povrchu se nacházely kuličky z organického materiálu, určeného rovněž Janem Novákem jako semena konopí setého. Nálezová situace nutí vážně uvažovat o využití této rostliny jako květinové výzdoby křiže. Povrch kříže pokrývají bronzové či měděné plíšky opatřené vybíjenými body, prostými kovovými pásky přichycenými drobnými hřebíčky byly opatřeny i boky kříže. Dle dochovaných zbytků šlo o kř́íž dvouramenný, způsob ukončení ramen není bohužel patrný. Na místě kř́ižení delšího břevna visí plechový korpus Ježíše Krista. Dle uvedených znaků jde nepochybně o ostatkový kříž určený k výstavu partikule (částečky) Pravého kříže (k problematice a terminologii Štajnochr 2011, 7, 21). Způsob uložení partikule (např. v objímce či kovové schráně) není patrný, partikule se nedochovala nebo ji nelze identifikovat. Oproti jiným, bohatě vypraveným ostatkovým křížům představujícím nezřídka vrchol soudobé šperkařské práce s využitím drahých kovů a vzácných kamenů (řada př́ikladů viz Štajnochr 2011) působí kř́iž z Hrádník prostým dojmem, i když vzhledem k dochovaným oválným otvorům musíme použití skla nebo drahých kamenů předpokládat. Ovšem ani kompletní proplavení celého objemu vykopané zeminy z okolí křŕže žádný takový nález nepřineslo. K ostatkovému kříži z Hrádník se mi z našeho území podařilo najít jedinou analogii objevenou při archeologickém výzkumu. Jde o ostatkový kříž nalezený v roce 2003 v hrobě ženy při archeologickém výzkumu rajského dvora johanitské komendy v Českém Dubu, datovaný do 12.-13. století, který však bohužel nebyl dosud souhrnně vyhodnocen (zatím pouze Černý-Stehlíková 2006, 181; Šilhová 2007; Otevři zahradu rajskou 2014, III.46; ${ }^{4}$ Edel-Matiášek-Žegklitzová 2014, 193-194, obr. 6). Nález ostatkového kříže v hradním prostředí je krajně neobvyklý, a bude proto vyžadovat samostatné detailní zhodnocení po dokončení konzervace.
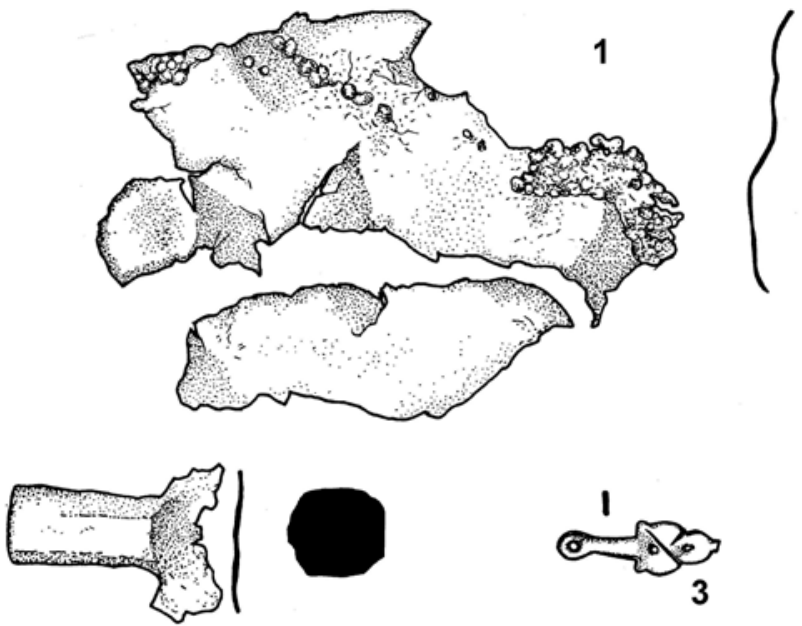

2
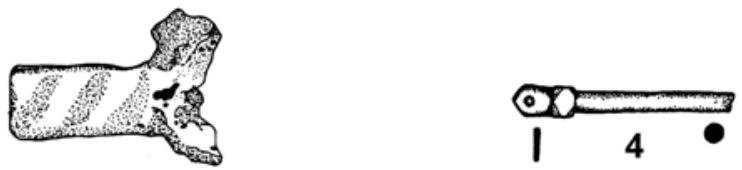

Obr. 24. Zářecká Lhota - Hrádníky. Předměty z barevných kovů. Abb. 24. Zářecká Lhota - Hrádníky. Gegenstände aus Edelmetall.

4 Autor se v uvedené publikaci skrývá pod iniciálami jv, tyto však v soupisu autorů nejsou uvedeny. 

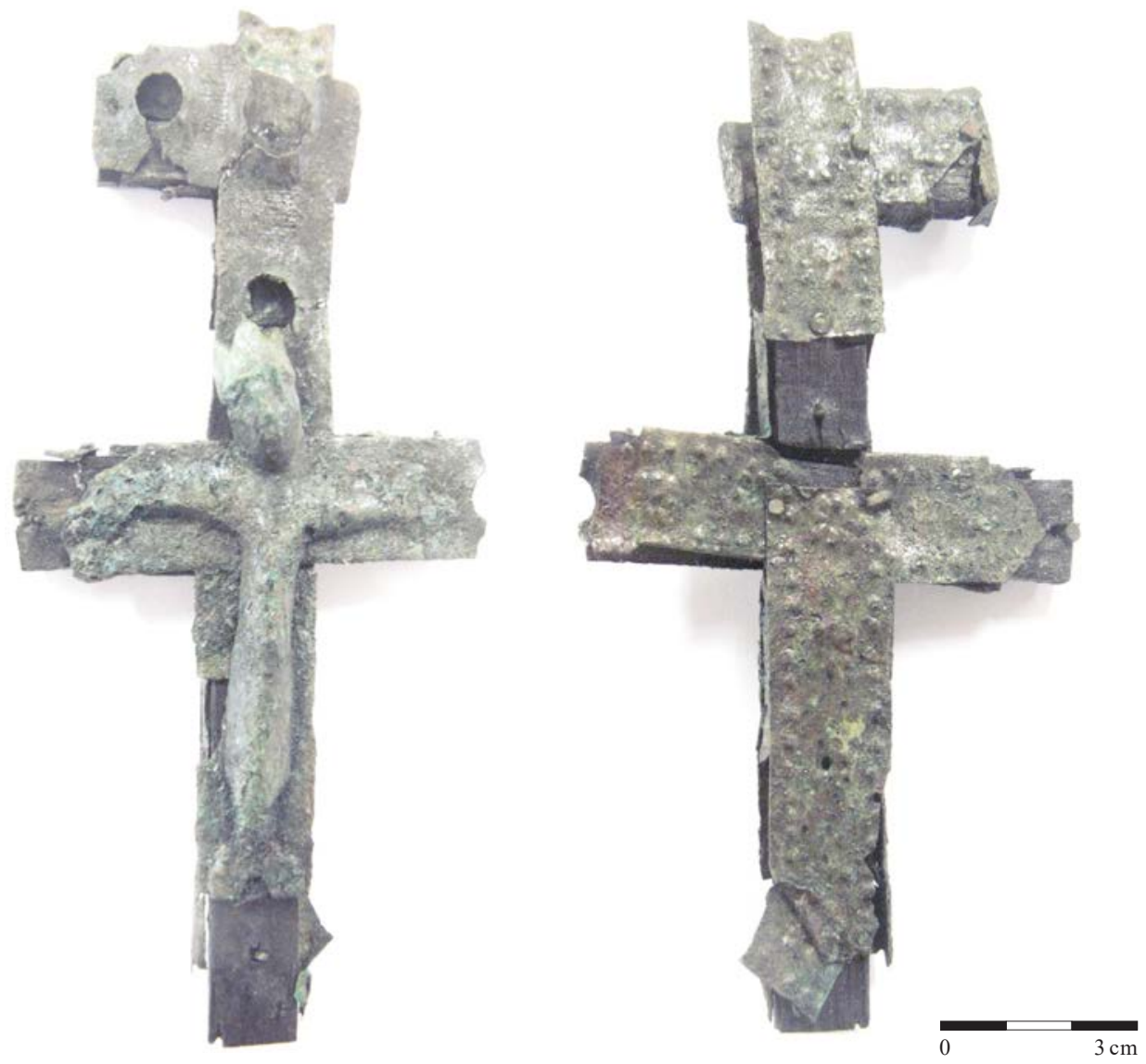

Obr. 25. Zářecká Lhota - Hrádníky. Ostatkový kříž.

Abb. 25. Zářecká Lhota - Hrádníky. Reliquienkreuz.

K hranolu ze slitiny mědi (bronz?) s jednou plochou opatřenou imitací tordování, na jednom konci ploše roztavenému (obr. 24:2) se mi adekvátní analogii zjistit nepodařilo. Recentní, např. barokní datování nelze vzhledem k místu nálezu (samý okraj vkopu pro udírnu) sice vyloučit, proti však hovoří prrítomnost dalších artefaktů, z nichž část je prokazatelně vrcholně středověkého stáŕí.

Situace na místě nálezu kříže objeveného mezi jinými předměty vyvolává celou řadu dalších otázek. Železné předměty, některé jen obtížně určitelné, a konec konců i hranolový artefakt nesoucí na jednom konci jasné známky tavení, budí představu skladu kovového odpadu určeného k recyklaci. Do této představy však absolutně nezapadá takový mimořádný předmět, jakým ostatkový kř́iž (nebo jeho podstatná část) nepochybně byl. Předměty sakrální povahy byly vždy předmětem značné úcty, zohlednit musíme i minimální množství použitého kovu, navíc do poslední chvíle připevněného na dřevěném podkladu. Říci můžeme jenom to, že situace snad nějak odráží dramatické okamžiky související s koncem lokality. Více světla by do celé situace mohl vnést plošný odkryv, otázkou ovšem zůstává, jakou část výjimečné nálezové situace zničil výkop pro stavbu chaty.

Další klasifikaci neumožňuje ani natavený rozlomený bronzový plech (obr. 24:1), do vrcholného středověku ovšem spolehlivě datovaný stratigraficky, s nímž zřejmě souvisí drobné útržky měděného plechu nacházené v okolí stratifikovaného nálezu při povrchu (a nezřídka druhotně pohozené). 


\subsection{Předměty z drahých kovi̊}

23. slitek stříbra, max. 22 mm, E 0589601, N 5539190, hl. 10 cm v šedé humusové

58. více než 90 ks slitků stř́bra o max. velikosti 47 mm, celková hmotnost 300 g, E 0589603 , N 5539188, v šedočerné humusové písčitojílovité na ploše ca $5 \times 5 \mathrm{~m}$

59. slitek stř́bra, max. 16 mm, 3,38 g, E 0589620, N 5539172, na povrchu pod listím na dně př́kopu

56. parvus Václava II., $15,0 \times 14,5 \mathrm{~mm}, 0,31 \mathrm{~g}$, E 0589606, N 5539196, hl. 8 cm v šedočerné humusové písčitojílovité vrstvě nad kameny (obr. 26)

61. parvus Václava II., 16,0 × 15,3 mm, 0,32 g, E 0589574, N 5539190, hl. do 5 cm v druhotně přemístěné zemině v okolí moderního ohniště (obr. 27)

V hradním prostředí opět dosti neobvyklým jevem je kumulace zcela amorfních slitků stříbra detekovaná na ploše ca $5 \times 5 \mathrm{~m}$ na plošině mezi př́ičným valem a př́íkopem (obr. 10 ). Největší kus kovu dosahuje velikosti 47 mm a hmotnosti 35,51 g, což je ovšem výjimka, většina slitků je mnohem menších v řádech milimetrů až centimetru. Celkem se podařilo dohledat více než 90 slitků o celkové váze 300 g, počet však není zcela jistě konečný. Amorfní kousky kovů se soustřred’ovaly do tmavé povrchové humusové vrstvy, zkusmá skrývka této povrchové uloženiny na hlouběji uloženou šedookroovou vrstvu ukázala, že se kov nachází i v ní, a stř́ibro je tudíž nepochybně vrcholně středověkého původu. Do intaktní stř̌edověké vrstvy však již nebylo zasahováno. Solitérní slitek jsme volně pod listím nalezli i na dně př́kopu, patrně se sem dostal vlivem eroze, popř. jako nerozpoznané stř́bro (řada slitků nese na povrchu vysrážené zelené oxidy mědi) mohl být i pohozen při provádění nelegálního detektorového průzkumu.

Velmi vítaným nálezem jsou mince reprezentované v dané lokalitě dvěma parvy Václava II. (obr. 26-27). Tyto mince byly raženy souběžně s pražskými groši minimálně v letech 1300-1305 jako drobné nominály v hodnotě 12 parvů (,parvi pragenses“) za jeden pražský groš (Castelin 1953, 33-35). Parvy byly donedávna vzácné, protože se s nimi v hromadných nálezech setkáváme pouze ojediněle (nejbliže v depotu z Běstovic, v němž byly vedle 126 pražských grošů Václava II. a Jana Lucemburského také čtyři parvy Václava II. - Smolík 1884, 257). Situaci změnily až archeologické výzkumy a detektorové nálezy, přinášející nálezy parvů jako ztrátových mincí (Militký-Šlézar 2007, 229). Jejich nález na opevnění v Hrádníkách je velmi důležitý z chronologického hlediska, parvy totiž nezůstaly dlouho v oběhu a byly pro svou ryzost záhy roztavovány.

Na ploše s koncentrací slitkového stř́ibra se setkáváme nejen s neobvyklým množstvím neraženého drahého kovu, běžně používaného (i když obvykle v trochu jiné formě) v našich zemích ve 13. století jako alternativa oběživa (Petrtyl 1976), ale i s jedním kusem raženého kovu v podobě parvu Václava II. a zlomkem skládacích vážek. I když všechny uvedené nálezy pocházejí bez výjimky z povrchové humusové vrstvy (pouze u slitkového stř́ibra víme, že se vyskytuje i hlouběji) a zlomek skládacích vážek př́mo z povrchu pravděpodobně v důsledku nelegálních detektorových aktivit (je dokonce možné, že zde došlo k výraznému narušení významné archeologické situace spojenému s odcizením části předmětů ${ }^{5}$ ), nebude tato skutečnost patrně náhodná. Protože
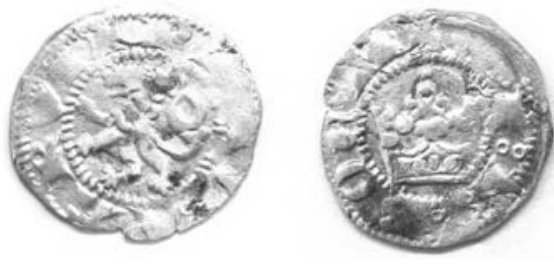

Obr. 26. Zářecká Lhota - Hrádníky. Parvus Václava II. Abb. 26. Zářecká Lhota - Hrádníky. Parvus von Wenzel II.
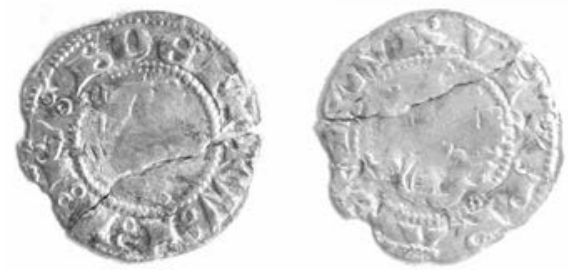

Obr. 27. Zářecká Lhota - Hrádníky. Parvus Václava II. Abb. 27. Zářecká Lhota - Hrádníky. Parvus von Wenzel II.

5 Orientační detektorový průzkum provedený v daném prostoru autorem v listopadu 2009 zde i přes použití hloubkové S.E.F. cívky na detektoru F75 žádné předměty z barevných kovů (již?) nezaznamenal. Nelegální aktivity s využitím detektorů kovů zde máme doloženy př́mým svědectvím současné majitelky chaty. 
vzhledem ke geologickým poměrům na Choceňsku můžeme s jistotou vyloučit souvislost s montánní činností, nabízí se jako nejpravděpodobnější logické vysvětlení souvislost s obchodem.

\section{Movité nálezy z okolí hradu}

\section{K. ú. Zářecká Lhota}

18. torzo ostruhy s velkým kolečkem v krátké vidlici, ramena odlomena, max. $90 \mathrm{~mm}$, E 0589645, N 5539127, širší předpolí fortifikace, hl. $20 \mathrm{~cm}$, z toho $7 \mathrm{~cm}$ šedá humusová písčitojílovitá a $13 \mathrm{~cm}$ podložní šedookrová jílovitopísčitá (obr. 28:3)

19. přezka osmičkovitého tvaru ze slitiny mědi s dochovaným trnem, $40 \times 32 \times 8 \mathrm{~mm}$, E 0589540, N 5539174, hl. 8 cm v šedé humusové jílovitopísčité na (částečně úvozové) cestě pod hradem (obr. 28:2)

\section{K. ú. Oucmanice}

1. hrot šípu s trnem, $101 \times 10 \times 6$ mm, E 0590163 , N 5538837, v humusové vrstvě těsně pod povrchem na prudkém svahu $\mathrm{k}$ Tiché Orlici (obr. 28:1)

$\mathrm{Z}$ cesty pod hradem pochází dvoudílná, či v tomto případě přesněji osmičkovitá přezka (k terminologii Zůbek 2002, 132) zhotovená ze slitiny mědi (obr. 28:2). Zatímco v zahraničí je vrcholně středověkým přezkám věnována adekvátní pozornost, at' již samostatně, či jako součástem oděvu nebo obecně jako předmětům z barevných kovů (Fingerlin 1971; Heindel 1990; Egan-Pritchard a kol. 1991; Wachowski 1994; Krabath 2001, 131-158; Lungerhausen 2004, 24-38), v českých zemích a na Slovensku se studiemi zaměřenými na tento specifický typ kovové industrie setkáváme zatím spíše ojediněle (Ruttkay 1989; Měřínský 1991; Richterová 1996a; Zůbek 2002; Unger 2011). V zahraničí je uváděna obliba dvojitých přezek s širším spektrem využití pro delší časové období (Heindel 1990, 22), v dané podobě a velikosti však až od druhé poloviny 14. a především v 15. století (Fingerlin 1971, 182; Egan-Pritchard a kol. 2002, 22, 82-89). Nepřekvapí proto, že se v českých zemích a na Slovensku setkáváme s těmito výrobky na lokalitách existujících či přímo zaniklých v 15. století, jako Vízmburk (Koštál a kol. 2013, 141, obr. 89, tab. 61:6), Devínský hrad (Polla-Egyházy-Jurovská 1975, 109, obr. 1:2), Rokštejn (Měřínský 2007, obr. 67:16-17), Brno (Měchurová 1991, 146, tab. II:5); do druhé poloviny 14. až první třetiny 15. století se dají datovat železné přezky nalezené v hrobech v interiéru kostela v Rákoši (Fủryová 2011, 425, obr. 6:3,4). Časněji je datován exemplář z hradu ve Starém mestě v Banské Štiavnici (Labuda 2000, 16, obr. 6:2).
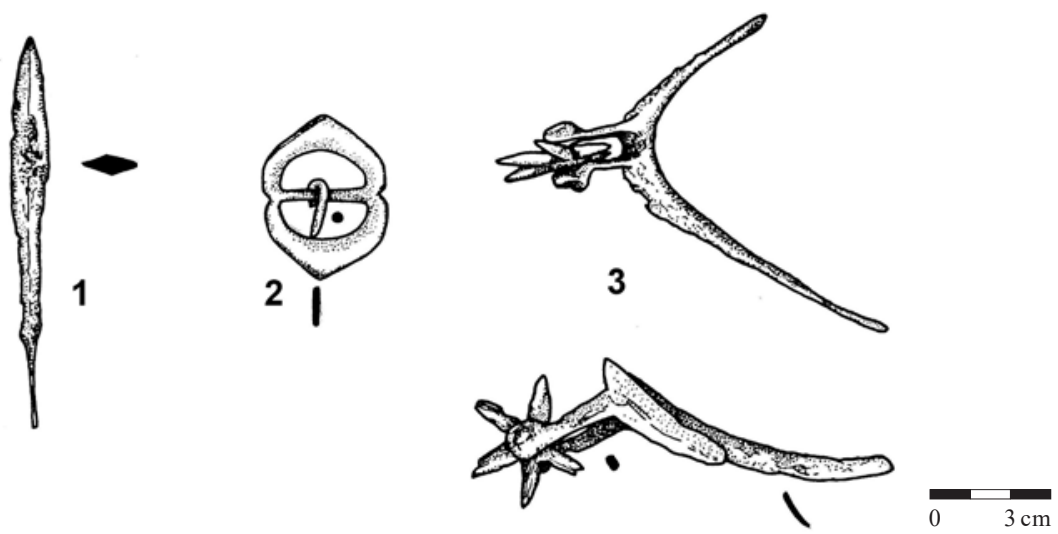

Obr. 28. Předměty mimo areál fortifikace. 1 - k. ú. Oucmanice, svah k Tiché Orlici vně pravěkého hradiště poblíž pravěkého valu přepažujícího ostrožnu; 2 - k. ú. Zářecká Lhota, přezka z úvozové cesty pod hradem; 3 - k. ú. Zářecká Lhota, ostruha z předpolí hradu.

Abb. 28. Gegenstände außerhalb des Befestigungsareals. 1 - Katastergebiet Oucmanice, Hang zur Stillen Adler außerhalb des urzeitlichen Burgwalls in der Nähe des den Bergsporn teilenden urzeitlichen Walles; 2 - Katastergebiet Zářecká Lhota, Schnalle aus dem Hohlweg unterhalb der Burg; 3 - Katastergebiet Zářecká Lhota, Sporn aus dem Burgvorfeld. 
Železná ostruha z předpolí hradu má odlomená ramena s koncovými úchyty, které patř́i k chronologicky citlivým prvkům. Vzhledem ke krátké vidlici s kolečkem a náznaku prohnutí ramen jde pravděpodobně o analogický typ jako u ostruh zjištěných v areálu hradu (obr. 28:3).

Hrot šípu z k. ú. Oucmanice byl nalezen ve vzdálenosti zhruba $700 \mathrm{~m}$ jihovýchodně od hradu, proto se jeho souvislost s hradem jeví jako problematická. Hrot šípu (obr. 28:1) ovšem nachází nejbližší věrné analogie v kolekci hrotů šípů z hradu s př́íslušnými typologicko-chronologickými závěry. Velmi zajímavý depot osmi pražských grošů nalezený na ploše $30 \times 50 \mathrm{~cm}$ s rozptylem mincí do hloubky $30 \mathrm{~cm}$ v prudkém svahu u paty skály na svahu k Tiché Orlici v k. ú. Oucmanice nachází časově věrný protějšek v parvech Václava II. získaných v areálu hradu, depot však byl již zevrubně vyhodnocen samostatně (Militký-Vích 2011).

$\mathrm{V}$ roce 1881 byl ve vzdálenosti 400-600 m východním směrem od hradu u Mitkovského mlýna náhodně při dobývání pařezů objeven v nádobce depot více než 4200 denárů z přelomu 12. a 13. století (Smolík 1881, 593-594).

\section{Závěr}

Hrad v poloze Hrádníky v k. ú. Zářecká Lhota byl zbudován s využitím kamene, dřeva a hlíny. Konec života lokality byl spojen s výraznou požárovou událostí, stopy válečných aktivit se však prokázat nepodařilo. Pokud při dramatických událostech spojených se zánikem hradu hrálo vojenství nějakou roli, muselo jít o rychlou akci (překvapivý přepad?) nezanechávající archeologických stop. Analýza hmotných pramenů ukazuje, že ke vzniku fortifikace došlo v samém závěru 13. či spíše na samém počátku 14. století a doba existence fortifikace nepřesáhla první polovinu 14. století, spíše však byla výrazně kratší směrem k počátku tohoto věku. Přes postižení pramenů rabovacími aktivitami se podařilo získat kolekci předmětů dokládající běžný každodenní život na hradě. Mimoto některé artefakty v hradním prostředí málo obvyklé (slitky stříbra, zlomek vážek) či zcela výjimečné (torzo ostatkového křriže) signalizují vazbu na specifické aktivity či vyšší sociální prostředí.

Těžko zodpověditelná zůstává otázka po zakladateli a majiteli hradu. Především datování lokality nabízí určitý prostor pro ztotožnění opevnění s hradem Václava II., o jehož plánovaném založení se dozvídáme z písemného pramene konce 13. století. V úvahu je však třeba vzít i skutečnosti, které tuto hypotézu nepodporují. Je to např. otázka po př́ičinách zakládání nové fortifikace v situaci, kdy je sít' zeměpanských hradů již plně vybudována a konsolidována, otázka velikosti a podoby hradu apod., přičemž na některé z těchto otázek může přinést odpovědi další výzkum (archeologický odkryv, geofyzikální měření). V úvahu musíme vzít i jiné možnosti vysvětlení, jako činnost lapků, šlechtické sídlo spojené s nějakými specifickými aktivitami, jako např. obchod vázaný na nějakou komunikaci (skládací vážky, slitkové stříbro) apod.

Lokalita i přes četné recentní zásahy zůstává mimořádnou památkou. V požárových vrstvách a pod nimi se stále skrývá množství informací osvětlujících pohnutou minulost hradu.

Příspěvek byl vypracován $\mathrm{v}$ rámci programu aplikovaného výzkumu a vývoje národní a kulturní identity (NAKI II) č. DG16P02R031 (Moravské křižovatky).

Pokud není uvedeno jinak, foto autor 4. 3. 2015. Kresba všech kovových artefaktů Kristýna Urbanová.

\section{Prameny}

BLÁHOVÁ, J. a kol., 1987: Kroniky doby Karla IV. Praha.

CDB II: Codex diplomaticus et epistolaris regni Bohemiae V/1 (Friedrich, G., ed.). Praha 1912.

LOSERTH, J., 1896: Das St. Pauler Formular. Briefe und Urkunden aus der Zeit König Wenzeles II. Gefunden und herausgegeben von Johann Loserth. Prag.

RBM IV: Regesta diplomatica nec non epistolaria Bohemiae et Moraviae IV, 1333-1346 (Emler, J., ed.). Pragae 1892. 


\section{Literatura}

BELCREDI, L., 1989: Terminologie, tř́iění a kód středověkých kovových předmětů - Terminologie, Klassifizierung und Kode mittelalterliche metalischer Gegenstände, AH 14, 437-472.

BURIAN, V., 1960: Nálezy z husitského opevnění kartouzky v Dolanech - Funde aus der Hussittenfeste Kartouzky in Dolany bei Olomouc, AR XII, 204-212.

- 1971: Výzkum hradu Tepence (obec Jívová) roku 1970, PV 1970, 65-68.

- 1973: Výzkum kartuziánského kláštera v Dolanech (okr. Olomouc), PV 1972, 84-86.

CASTELIN, K., 1953: Česká drobná mince doby předhusitské a husitské 1300-1471. Praha.

CEJPOVÁ, M., 2002: Hrad Hlavačov, okr. Ústí nad Orlicí - Die Burg Hlavačov, Bezirk Ústí nad Orlicí, CB 8, 131-138.

- 2006: Zjišt’ovací výzkum hradu Hlavačova u Chocně - Zur Unterzuchung der Burg Hlavačov bei Choceň, CB 10, 131-146.

ČAPLOVIČ, D., 1983: Doklady domácej a remeslnej výroby v stredovekých dedinách na východnom Slovensku - Belege der Heimarbeit und handwerklichen Erzeugen in mittelalterlichen Dörfen der Ostslowakei, AH 8, 373-383.

ČERNÁ, L.-STANĚK, P.-ZŮBEK, A., 2010: Hrádek Rumberk - archeologický výzkum v roce 2009 Burg Rumberk - archäologische Ausgrabungen im Jahre 2009, CB 12, 415-452.

ČERNÝ, P.-STEHLÍKOVÁ, D., 2006: Zlatnictví, emailérství a kovolitectví. In: Du bon du coeur. Poklady francouzského středověkého umění v českých a moravských sbírkách (Černý, P., ed.), 179-182. Olomouc.

DOLEŽEL, J., 2007: Na okraj nálezů středověkých skládacích vážek z českých zemí. In: Od knížat ke králům. Sborník u př́ležitosti 60. narozenin Josefa Žemličky (Doležalová, E.-Šimůnek, R., edd.), 147-157, 581-582. Praha.

DRDA, M., 1978: Soubor nálezů ze Sezimova Ústí, Husitský Tábor 1, 7-29.

- 1983: Archeologický výzkum čp. 39 v Táboře - Archaeological excavations in the house No. 39 at the town of Tábor, AR XXXV, 274-283.

DRNOVSKÝ, P., 2012: „Tvrz“v Třebověticích. Hmotná kultura středověkého a raně novověkého sídla ve východních Čechách - "The Fortified Manor" in Třebovětice. Material Culture of Medieval and Early Modern Period Residence in Eastern Bohemia, Studia Mediaevalia Pragensia 11, 177-226.

DROBNÝ, T., 1995: Vývoj středověkých ostruh od 11. do počátku 16. století. Nepublikovaná diplomová práce, ÚAM FF MU, Brno.

DURDÍK, T., 1972: K problematice středověkých šipek v Československu, Zpravodaj klubu vojenské historie $2 / 4-6,3 / 5-9$.

- 1976: Nálezy z hradu Týřova I. Katalog starších sbírek, Zprávy Čs. společnosti archeologické při Čs. akademii věd XVIII/3-6. Praha - Nitra - Brno.

- 1989: Železné předměty z hradu Rábí - Eisengegenstände aus der Burg Rábí, CB 1, 279-294.

DURDÍK, T.-FROLÍK, J., 1993: Hrad Vildštejn na Chrudimsku - Die Burg Vildštejn bei Chrudim, CB 3, 47-72.

EGAN, G.-PRITCHARD, F. a kol., 2002: Dress Accessories C. 1150-C. 1450. Medieval finds from excavations in London 3. London.

EDEL, T.-MATIÁŠEK, J.-ŽEGKLITZOVÁ, J., 2014: Stavební vývoj českodubské johanitské komendy sv. Ducha od 40. let 13. století do roku 1429 - The Construction Development of St John's Commandery of the Holy Spirit in Český Dub from the 1240s until 1429. In: Středověká Evropa v pohybu. K poctě Jana Klápště - Medieval Europe in Motion in Honour of Jan Klápště (Boháčová, I.-Sommer, P., edd.), 185-198. Praha.

FINGERLIN, I., 1971: Gürtel des hohen und späten Mittelalters. Berlin.

FROLÍK, J., 2002: Nálezy z obléhání hradu Lichnice v letech 1428-1429 - Fundstoff aus der Belagerung der Burg Lichnice in den Jahren 1428-1429, CB 8, 399-408.

FÜRYOVÁ, K., 2011: Románsky kostol v Rákoši - Die romanische Kirche in Rákoš, AH 36, 423-430.

GOŠ, V., 1986: Kolekce kovových předmětů slovanské osady v Mohelnici, ČSM 35, 193-200.

HANULIAK, V., 1983: Odkryté zvyšky kováčskej vyhne na Liptovskom hrade - Freigelegte Reste einer Schmiedeesse auf der Burg Liptovský hrad, AH 8, 479-490.

- 1986: K stavebno-funkčnej interpretácii obytného objektu z Chlaby - Zur funktionellen Interpretation eines Wohnobjektes aus Chl'aba, AH 11, 469-478.

HAVEL, J., 1980: Hromadný hrob bělohorských bojovníků - Ein Massengrab der Krieger vom Weißen Berg (Bílá hora), Archaeologia Pragensia 1, 227-231.

HEINDEL, I., 1990: Riemen- und Gürtelteile im westslawischen Siedlungsgebiet. Berlin. 
HEJNA, A., 1959: Dva nálezy železného nářadí v severovýchodních Čechách - Deux trouvailles d'outils en fer de la Bohême du nord-est, AR XI, 110-112.

- 1983: Kovový nálezový inventář z hradu Vizmburku, k. ú. Havlovice - Das Fundinventar metallischer Gegenstände aus Burg Vizmburk, Katastralgemeinde Havlovice, Bez. Trutnov, AH 8, 491-501.

HOLTMANN, G. F. W., 1993: Untersuchung zu mittelalterichen und frühneuzeitlichen Messern dargestellt am Beispielen von archäologischen Funden vornehmlich aus dem weiteren Küstenbereich von Nord- und Ostsee bis zur Mittelgebirgszone. Göttingen.

HRUBEC, I., 1971: Výzkum zaniknutej dediny Dolný Poltár - Grabungen in der Dorfwüstung Dolný Poltár, AR XXIII, 69-79.

HUML, V., 1967: Zaniklá tvrz Semonice - Die untergegangene Festung in Semonice. Fontes Musei Reginaehradecensis Supplementum II. Hradec Králové.

HYLMAROVÁ, L.-KLÍR, T.-ČERNÁ, E., 2013: Železné předměty ze zaniklého Spindelbachu v Krušných horách. K výpovědi detektorového průzkumu - Eisengegnstände aus der Wüstung Spindelbach im Erzgebirge. Zur Aussagekraft einer Detektorsuche, AH 38, 569-609.

JANSKÁ, E., 1963: Archeologický výzkum hradu Sión - Archäologische Untersuchung der Burg Sión, AR $\mathrm{XV}, 220-247$.

JEŽEK, M., 2002: Odkrycia wag składanych w krajach czeskich. In: Civitas \& villa. Miasto i wieś w średniowiecznej Europie środkovej (Buśko, C.-Klápště, J.-Leciejewicz, L.-Moździoch, S., edd.), 453-456. Wrocław - Praha.

KAŹMIERCZYK, J. 1978: Podkowy na Śłasku w X-XIV wieku. Wrocław - Warszawa - Kraków - Gdańsk. KLÍMA, B., 1980: Zámečnická práce staromoravských kovářů v Mikulčicích. Praha.

KOÓŠOVÁ, P., 2004: Ku klasifikácii vrcholnostredovekých ostrôh z územia Slovenska (12.-15. storočie) Zur Klassifikation der hochmittelalterlichen Sporen auf dem Gebiet der Slowakei (12.-15. Jahrhundert), AH 29, 523-547.

KOŠŤÁL, J. a kol., 2013: Vízmburk. Př́iběh ztraceného hradu. Havlovice.

KRABATH, S., 2001: Die hoch- und spätmittelalterlichen Buntmetallfunde nördlich der Alpen. Eine archäologisch-kunsthistorische Untersuchung zu ihrer Herstellungstechnik, funktionalen und zeitlichen Bestimmung. Rahden/Westf.

KRAJÍC, R., 1991: Stavební železo a uzavírací mechanismy na vrcholně středověkých lokalitách Táborska - Eiserne Baubeschläge und Verschließungsmechanismen von den hochmittelalterlichen Lokalitäten in Gegend von Tábor, AH 16, 323-344.

- 2003: Sezimovo Ústí. Archeologie středověkého poddanského města 3. Kovárna v Sezimově Ústí a analýza výrobků ze železa, díl I. Praha - Sezimovo Ústí - Tábor.

LABUDA, J., 1999: Pozoruhodné nálezy z Hradu na Sitne - Beachtenswerte Funde aus Burg in Sitno bei Banská Štiavnica, AH 24, 217-230.

- 2000: Pozoruhodné nálezy zo Starého mesta v Banskej Štiavnici - Beachtenswerte Funde aus „Staré mesto“ in Banská Štiavnica, AH 25, 7-24.

LOCHMANN, Z. A., 1985: Nálezy ze středověkého objektu v Praze 10 - Záběhlicích - Funde aus einem mittelalterlichen Objekt aus Prag 10 - Záběhlice, Archaeologia Pragensia 6, 191-202.

LUNGERHAUSEN, A., 2004: Buntmetallfunde und Handwerksrelikte des Mittelalters und der frühen Neuzeit aus archäologischen Untersuchungen in Braunschweig. Rahden/Westf.

MĚCHUROVÁ, Z., 1984: Součásti uzdění koně ve velkomoravském období - Die Bestandteile der Raitpferdzäumung in der mittleren Burgwallzeit, AH 9, 263-292.

- 1991: Předběžné výsledky výzkumů na Kapucínském nám. 5 a 8 v Brně - Vorläufige Ergenisse der Rettungsgrabung auf dem Kapucínské náměstí (Kapuzinerplatz) Nr. 5 und 8 in Brno, AH 16, 145-168.

- 1995: Železné předměty ze zaniklé středověké vsi Konůvky na Slavkovsku (okr. Vyškov) - Eiserne Gegenstände aus der mittelalterlichen Ortswüstung Konůvky nächst Slavkov (Austerlitz), Bez. Vyškov, Acta Musei Moraviae Scientiae sociales LXXX, 141-197.

- 1997: Konůvky - zaniklá středověká ves ve Ždánickém lese. Praha.

MERTA, J., 1974: Nález válečkového zámku a klíče na středověké fortifikaci pod Novým Hradem, VVM XXVI, 165-169.

MĚŘÍNSKÝ, Z., 1991: K chronologickému postavení přezek se zdobeným kruhovým rámečkem a zeslabením v místě uchycení očka trnu. In: Sborník Společnosti přátel starožitností 2, 75-78. Praha.

-2007: Hrad Rokštejn. Dějiny, stavební vývoj a výsledky čtvrtstoletí archeologického výzkumu 1981-2006. Brtnice - Brno.

MICHNA, P., 1979: Středověké mincovní vážky z Olomouce - Die mittelalterliche Klappwaage aus Olmütz in Mähren, VVM XXXI, 38-48.

MILITKÝ, J.-ŠLÉZAR, P., 2007: Nálezy středověkých mincí objevených při archeologickém výzkumu v Olomouci, Numismatický sborník 22, 223-231. 
MILITKÝ, J.-VÍCH, D., 2011: Hromadný nález pražských grošů Václava II. z Oucmanic (okr. Ústí nad Orlicí), Numismatický sborník 26, 138-142.

MUSIL, F., 1995: Hrady, tvrze a zámky okresu Ústí na Orlicí. Ústí nad Orlicí.

- 2002: Osídlování Poorlicka v době př́edhusitské. Kraj na Tiché Orlici v povodí Třebovky a Moravské Sázavy. Ústí nad Orlicí.

NADOLSKI, A., 1954: Studia nad uzbrojeniem polskim w X, XI i XII wieku. Łódź.

NEKUDA, V., 1975: Pfaffenschlag. Zaniklá středověká ves u Slavonic. Brno.

- 1985: Mstěnice. Zaniklá středověká ves 1. Hrádek - tvrz - dvůr - předsunuté opevnění. Brno.

NEKUDA, R.-NEKUDA, V., 1997: Mstěnice. Zaniklá středověká ves u Hrotovic 2. Dům a dvůr ve středověké vesnici. Brno.

OTEVŘI ZAHRADU RAJSKOU, 2014: Otevři zahradu rajskou. Benediktini v srdci Evropy 800-1300 (Foltýn, D.-Klípa, J.-Mašková, P.-Sommer, P.-Vlnas, V., edd.). Praha.

PETRTYL, J., 1976: Funkce slitkového stř́ibra v našich zemích ve 13. stol. In: Sborník II. numismatického symposia 1969 (Sejbal, J., ed.), 85-105. Brno.

PLEINER, R., 1969: Středověké sídliště s kovárnami u Mutějovic - Eine mittelalterliche Dorfsiedlung mit Schmiedewerkstätten bei Mutějovice, PA LX, 533-571.

POLLA, B., 1962: Stredoveká zaniknutá osada na Spiši (Zalužany). Bratislava.

POLLA, B.-EGYHÁZY-JUROVSKÁ, B., 1975: Stredoveké pamiatky hmotnej kultúry z archeologických výskumov na Devínskom hrade - Mittelalterliche Denkmäler der materiellen Kultur aus archäologischen Grabungen auf der Burg Devín, ZbSNM LXIX, 97-168.

PROFANTOVÁ, N.-VÍCH, D., 2012: Zlacený vrchlík z Bošína (okr. Ústí nad Orlicí) a problém dokladů př́tomnosti raně středověké elity ve východních Čechách - Gilded cap from Bošín (Ústí nad Orlicí district) and evidence of the presence of an early medieval elite in Eastern Bohemia. In: Mezi raným a vrcholným stř̌edověkem. Pavlu Kouřilovi k šedesátým narozeninám přátelé, kolegové a žáci (Doležel, J.-Wihoda, M., edd.), 197-207. Brno.

RASL, Z., 1987: K typologii a konstrukci středověkých zámků. In: Sborník „Zkoumání výrobních objektů a technologií archeologickými metodami“, 146-165. Brno.

RICHTER, M., 1963: Raně stř̌edověké bronzové skládací vážky z Čech - Frühmittelalterliche Bronzeklappwagen aus Böhmen. In: Sborník Československé společnosti archeologické (K problémům prehistorie na Moravě a v sousedních oblastech) 3 (Tichý, R., ed.), 141-148. Brno.

- 1982: Hradišt'ko u Davle. Městečko ostrovského kláštera. Praha.

RICHTER, M.-VOKOLEK, V., 1995: Hradec Králové. Slovanské hradiště a počátky středověkého města. Hradec Králové - Praha.

RICHTEROVÁ, J., 1996: Středověké osídlení v povodí středního toku Rokytky - Die mittelalerliche Besiedlung im Einzugsgebiet des mittleren Laufes des Baches Rokytka, Archaeologia Pragensia 12, 273-307.

- 1996a: Kruhové přezky z výzkumu na Jungmannově náměstí v Praze - Ringförmige Schnallen aus der Forschung auf dem Jungmannplatz in Prag, AH 12, 493-498.

RUTTKAY, A., 1976: Waffen und Reiterausrüstung des 9. bis zur ersten Hälfte des 14. Jahrhunderts in der Slowakei (II), SlArch XXIV, 246-395.

- 1989: Prvky gotickej módy v odeve a ozdobách dedinského obyvatel'stva na území Slovenska (Horizont hrobov zo 14.-15. stor. v Ducovom, obec Moravany nad Váhom) - Elemente der gotischen Mode in Kleidung und Schmuck bei der ländlichen Bevölkerung auf dem Gebiet der Slowakei (Grabhorizont aus dem 14.-15. Jh. in Ducové, Gemeinde Moravany nad Váhom), AH 14, 355-378.

RUTTKAY, M.-CHEBEN, I.-RUTTKAYOVÁ, J., 1994: Výskum stredovekého opevneného sídliska v Branči-Vel'kej Vsi - Untersuchung der mittelalterlichen befestigten Siedlung in Branč-Vel'ká Ves, AH 19, 229-241.

RUSÓ, A., 1986: Architektura domu v Proseticích (okr. Teplice) - Die Architektur eines Hauses in Prosetice (Bez. Teplice), AH 11, 409-415.

SEDLÁČEK, A., 1883: Hrady, zámky a tvrze království českého II. Hradecko. Praha.

SLIVKA, M., 1981: Stredoveké hutníctvo a kováčstvo na východnom Slovensku, Historica Carpatica XII, 211-276.

SMOLÍK, J., 1881: Nález českých denárů a jejich rozbor, PA XI, 593-612.

- 1884: Dva nálezy mincí a krátká o nich úvaha, PA XII, 257-270.

STEUER, H., 1997: Waagen und Gewichte aus dem mittelalterlichen Schleswig. Funde des 11. bis 13. Jahrhunderts aus Europa als Quellen zur Handels- und Währungsgeschichte. Köln.

ŠAUEROVÁ, D., 1980: Středověké závěsné zámky z Konůvek na Slavkovsku - Mittelalterliche Vorhängeschlösser aus Konůvky in der Gegend von Slavkov, AR XXXII, 82-89. 
ŠILHOVÁ, A., 2007: Průzkum a restaurování ostatkového kř́iže z Českého Dubu. Konference konzervátorů a restaurátorů 4.-6. 9. 2007 Znojmo. Sborník z konference konzervátorů a restaurátorů, 88-90. Brno.

ŠTAJNOCHR, V., 2011: Kult španělského kř́iže. Praha.

UNGER, J., 1974: Archeologické nálezy z výzkumu hradu Melic na Vyškovsku (železné předměty), VVM XXVI, 194-201.

- 1981: Nálezy z objektu datovaného mincí na tvrzišti „Kulatý kopec“ u Žabčic (okr. Brno-venkov) - Funde aus einem münzdatieren Objekt auf der Motte „Kulatý kopec“ bei Žabčice, Bezirk Brno-Land, AH 6, 315-325.

- 1984: Zaniklá ves Topolany u Vranovic (okr. Břeclav) - Die Ortswüstung Topolany bei Vranovice, Kr. Břeclav, AH 9, 65-100.

- 1989: Feudální sídlo z 13. století na zaniklé vsi Koválov u Žabčic (archeologické nálezy). Mikulov.

- 1994: Koválov. Šlechtické sídlo z 13. století na jižní Moravě. Brno.

- 1999: Život na lelekovickém hradě ve 14. století. Brno.

- 2011: Přezky s kruhovým rámečkem jako součást mužského oděvu ve středověku - Round clasps as part of men's attire in the Middle Ages, AR LXIII, 644-665.

VENCL, S., 1971: Hradiště Hlavačov a Hrádníky na Choceňsku, Listy Orlického muzea VI, 17-32.

VÍCH, D., 2009: Orlické muzeum v Chocni. Katalog archeologické sbírky. Zprávy České archeologické společnosti - Supplément 74. Praha.

- 2010: Neznámá vrcholně středověká fortifikace na k. ú. Lanšperk - Unbekannnte hochmittelalterliche Fortifikation im Katastralgebiet Lanšperk, CB 12, 319-343.

- 2014: Kovové nálezy z hradu v Brandýse nad Orlicí - Metallfunde aus der Burg Brandýs nad Orlicí, CB 14, 142-155.

VOKOLEK, V., 1990: Hradiště lidu popelnicových polí v Zářecké Lhotě, Zpravodaj Krajského muzea východních Čech v Hradci Králové 17, 54-59.

- 1993: Výzkum lužického hradiště v Běstovicích, Zpravodaj muzea v Hradci Králové 19, 49-53.

WACHOWSKI, K., 1984: Militaria z grodu na Ostrówku w Opolu. In: Studia nad kulturą wczesnopolskiego Opola. Militaria - wyroby bursztynowe (Gediga, B., ed.), 11-112. Wrocław - Warszawa - Kraków - Gdańsk - Łódź.

- 1994: Profilierte Schnallen in Mitteleuropa, Zeitschrift für Archäologie des Mittelalters 22, $181-186$.

ZIMMERMANN, B., 2000: Mittelalterliche Geschossspitzen. Kulturhistorische, archäologische und archäometallurgische Untersuchengen. Schweitzer Beiträge zur Kulturgeschichte und Archäologie des Mittelalters 26. Basel.

ZŮBEK, A., 2002: Středověké přezky v brněnských nálezech - Medieval buckles from excavations of Brno, SPFFBU M 7, 123-153.

ŽÁKOVSKÝ, P. 2014: Tesáky a problematika jednosečných zbraní stř̌edověku a raného novověku. Nepublikovaná disertační práce, ÚAM FF MU Brno.

ŽÁKOVSKÝ, P.-HOŠEK, J. 2015: Kovové artefakty. In: Veselí nad Moravou. Středověký hrad v říční nivě (Plaček, M.-Dejmal, M., edd.), 220-251. Brno.

\section{Zusammenfassung}

\section{Eine Burg in Hrádníky bei Zářecká Lhota in der Region Choceň}

Über die Befestigung oberhalb der in der Nähe von Choceň gelegenen Siedlung Hrádníky (Katastergebiet Zářecká Lhota, Bezirk Ústí nad Orlicí, Landkreis Pardubice) lag uns bislang nur ein Minimum an Informationen vor. Die Situation wird bis zu einem gewissen Grad erst durch eine mit einer geodätischen Vermessung verbundenen Metalldetektoruntersuchung der Fundstelle geändert.

In der Umgebung von Choceň befinden sich insgesamt vier befestigte hochmittelalterliche Fundstellen (Abb. 1). Neben der untersuchten Befestigung in der sich im Katastergebiet befindenden Lage Zářecká Lhota handelt es sich bei dabei um die in der Nähe des Choceňer Friedhofs gelegene Burg Vranov-Koutníkov. Am linken Ufer des Flusses Stille Adler (Tichá Orlice) liegen auf einer ausgeprägten Terrasse zwei heute Hlavačov (13.-14. Jhdt.) und Zítkov (14.-15. Jhdt.) genannte Burgen. Jedoch kann man mit ihnen keine Erwähnung in den heute über Choceň verfügbaren Quellen mit Sicherheit in Verbindung bringen. 
Die hochmittelalterliche Befestigung in Hrádníky liegt ganz auf der Spitze eines von der Stillen Adler und dem Bach Ostrovecký Potok umflossenen Bergsporns (Abb. 2). Die Bauherren der Burg nutzten die aus Pläner-Felstürmen bestehende, ca. 320 m ü.d.M. strategisch günstig gelegene Stelle, wobei die gesamte Bergspornfläche bereits in der späten Bronzezeit zum Bau eines Burgwalls genutzt worden war. Die Burg wird vom Vorfeld durch einen $5 \mathrm{~m}$ tiefen und $20 \mathrm{~m}$ breiten, künstlich herausgebrochenen Graben getrennt (Abb. 3). Die Spuren anthropogener Aktivitäten im Vorfeld der Burg lassen sich weder mit Sicherheit datieren, noch interpretieren, die Frage nach der Existenz einer Vorburg bleibt deshalb offen. Im Innern der Burgfläche befindet sich oberhalb des Grabens eine rechteckige Fläche, deren Längsseiten quer zum Bergsporn verlaufen (Abb. 4), die Fläche oberhalb des Grabens wird vom inneren Burgareal durch einen deutlichen Wallkörper abgetrennt, der eine Steinmauer mit einer freigelegten Ecke in sich birgt (Abb. 5).

Der Innenraum der Befestigung (Abb. 6) wird durch eine Fläche gebildet, die an der Südund Nordseite von einem Wallkörper umgeben ist, der aus einer aus festgebranntem Lehmbewurf bestehenden Zerstörungsschicht besteht. Die Scheitelpartie des Burgareals wurde im Jahr 1938 durch den Bau einer Hütte zerstört (Musil 1995, 32), wodurch die Frage nach der Bebauung dieses Raumes wahrscheinlich definitiv geklärt wurde. Die intakte Situation wurde ferner auch von Begleitbauten gestört, die mit dem Betrieb der Hütte zusammenhängen. Am Südhang des Bergsporns befindet sich unterhalb der Felswand ein in den Pläner-Felsen gehauenes Objekt, das als Brunnen oder eher als Zisterne interpretiert wird (Abb. 7) und dessen Zusammenhang mit der Burg lediglich wahrscheinlicher Natur ist. Südlich von der Burg ist das Relikt eines Hohlwegs erhalten geblieben (Abb. 8, 10), dessen Zusammenhang mit der Burg ebenfalls nicht ganz offensichtlich ist.

Nähere Informationen über an der Fundstelle gemachte archäologische Funde liegen uns erst im Zusammenhang mit dem 1938 erfolgten Bau der Hütte vor (zwei Sporenfunde, Abb. 9:I). $\mathrm{Zu}$ einem weiteren Geländeeingriff, der zur Entdeckung von archäologischen Gegenständen führte, kam es am 10. 6. 1942 beim Ausgraben von Baumstümpfen vor dem die Mauer verdeckenden Querwall. Die gemachten Funde bestanden aus Keramik, Lehmbewurf und Metallgegenständen. Im Jahr 1964 haben Mitarbeiter des Museums des Adlergebirges in Choceň im Körper des Querwalls die bereits erwähnte Mauerecke freigelegt, die auch heute noch sichtbar ist und aus lose übereinandergeschichteten Bruchsteinen besteht. In die archäologische Fachliteratur gelangte die Burg erst durch das Verdienst von S. Vencl (1971, 22-29), der auch eine Planskizze der Fundstelle veröffentlichte.

In den Jahren 2009 und 2014-2015 wurde dort eine Oberflächenprospektion durchgeführt, die auch die Verwendung eines Metalldetektors durch den Verfasser und weiterer Mitarbeiter umfasste, wobei die Fundstelle zuvor bereits deutlich durch die illegale Verwendung von Metalldetektoren in Mitleidenschaft gezogen wurde. Bei der im Modus ALL METAL durchgeführten Detektorsuche wurden die Geräte Fisher 75, XP Deus, Teknetics T2, XP Goldmaxx Power II, AKA Signum, Nokta Fors Gold benutzt, dies mit einem Zeitaufwand von $42 \mathrm{~h}$ umgerechnet auf ein Gerät. Die Funde wurden mit einer GPS-Handstation (Schwemmschicht an den Hängen) und einer Totalstation (Befestigungsareal mit intakten Situationen, Abb. 10) vermessen. Außer der Keramik und den gemachten Einzelfunden von Metallgegenständen ist es noch gelungen, zwei Anhäufungen von Metallgegenständen zu entdecken (erste Anhäufung Abb. 11, 19; zweite Anhäufung Abb. 12; 13; 17:2-4; 23:5-7; 24:1; 25).

Die Keramik ist vertreten durch im Museum in Choceň aufgewahrte Funde älteren Datums (Auswahl in Abb. 14, nach Vích 2009) und durch die unlängst während der Untersuchung der Fundstelle gemachten Funde (Abb. 15). Diese bestehen zum Einen aus heller grauweißer bis ins Rötliche gehender Ware mit feinteiligem Magerungsmittel, die für gewöhnlich mit einer wulstartigen Spirale versehen ist, oft mit roter Bemalung. Viel häufiger aber begegnen wir einer Keramik mit grauen bis braunen Farbtönen und einem deutlichen sandigen Magerungsmittel sowie einer Glimmerbeimischung, die mit einem Spiralritzdekor versehen ist. Weniger deutlich kommt im Oxidationsbrand gebrannte Keramik mit roten Farbtönen und sandigem Magerungsmittel vor. Insgesamt macht die auf der Burg vertretene Keramikproduktion einen relativ homogenen Eindruck. Den zeitlichen Schwerpunkt des Fundkomplexes machen wir im älteren 
Abschnitt des 14. Jahrhunderts aus, eine ausgereifte hochmittelalterliche Keramikware vom Ende des 14.-15. Jahrhunderts treffen wir nicht an.

An Metallgegenständen sind Baubeschläge (Abb. 16-17), landwirtschaftliche Geräte (Abb. 18), Pferd- und Reiterausrüstung (Abb. 19-21), Militaria (Abb. 22), Gegenstände des persönlichen Bedarfs (Abb. 23:1-2) und sonstige Gegenstände (Abb. 23:3-7) vertreten, von denen lediglich ins 13.-14. Jahrhundert datierte Sporen chronologisch empfindlicher sind.

Von den Gegenständen aus Buntmetall (Abb. 24-25) sind das Balkenfragment einer Klappwaage (Abb. 24:4) und vor allem der Torso eines Reliquienkreuzes (Abb. 25) am interessantesten. Edelmetalle (Silber) kamen in Form von Gussstücken vor (300 g), die zwischen der in Form eines Walls erhaltenen Querwand und dem Graben gefunden wurden, ferner zwei Münzen, bei denen es sich in beiden Fällen um einen Parvus von Wenzel II. handelt (Abb. 26-27). Mehrere mittelalterliche Gegenstände stammen aus der Umgebung der Burg (Abb. 28).

Die Burg in der Lage Hrádníky im Katastergebiet Zářecká Lhota wurde aus Steinen, Holz und Lehm gebaut. Dass die Fundstelle aufgegeben wurde, ist mit einem gravierenden Brandereignis verbunden, Spuren von Kriegsaktivitäten konnten jedoch nicht nachgewiesen werden. Falls bei den mit dem Untergang verbundenen dramatischen Ereignissen das Kriegswesen irgendeine Rolle gespielt haben sollte, muss es sich dabei um eine schnell erfolgte Operation gehandelt haben, die keine archäologischen Spuren hinterlassen hat. Eine Analyse der materiellen Quellen hat ergeben, dass es ganz am Ende des 13. bzw. eher ganz zu Beginn des 14. Jahrunderts zur Entstehung der Befestigung gekommen ist, und die Dauer, während welcher die Befestigung existierte, nicht über die erste Hälfte des 14. Jahrhunderts hinausging, jedoch war sie eher noch deutlich kürzer in Richtung Anfang dieses Jahrhunderts. Neben gängigen Gegenständen verfügen wir auch über einige Artefakte, die für das Burgmilieu wenig üblich (Silbergussstücke, Fragmente einer Waage) oder völlig außergewöhnlich sind (Torso eines Reliquienkreuzes). Sie signalisieren, dass es eine Verbindung zu speziellen Aktivitäten oder zu einem höheren sozialen Milieu gegeben hat.

Nur schwer zu beantworten bleibt die Frage nach dem Gründer und Besitzer der Burg. Vor allem die Datierung der Fundstelle lässt gewissen Raum dafür, um die Befestigung mit einer Burg von Wenzel II. zu identifizieren, von deren geplanter Gründung wir aus einer schriftlichen Quelle vom Ende des 13. Jahrhunderts erfahren. Es müssen jedoch auch Tatsachen in Betracht gezogen werden, welche diese Hypothese nicht stützen. So etwa die Frage nach den Ursachen für die Gründung einer neuen Befestigung in einer Situation, als das Netz der landesherrlichen Burgen bereits vollständig ausgebaut und konsolidiert war, die Frage nach Größe und Form der Burg u.ä., wobei einige dieser Fragen (Form der Bebauung usw.) durch eine weitere Grabung beantwortet werden können. Auch andere Erklärungsmöglichkeiten müssen hier in Betracht gezogen werden, wie beispielsweise Aktivitäten von Wegelagerern, oder etwa als Adelssitz, der mit irgendwelchen speziellen Aktivitäten, wie beispielsweise mit dem an Verkehrswege gebundenen Handel verbunden waren u.ä.

Der vorliegende Beitrag wurde im Rahmen des Programms der angewandten Forschung und Entwicklung von nationaler und kultureller Identität ausgearbeitet (NAKI II) N. DG16P02R031 (Mährische Kreuzungen).

Falls nicht anders angegeben, Fotos David Vích, 4. 3. 2015. Zeichnungen aller Metallartefakte Kristýna Urbanová.

PhDr. David Vích, Regionální muzeum ve Vysokém Mýtě, Šemberova 125, 56601 Vysoké Mýto, Česká republika,dvich@centrum.cz 